Staff Working Paper/Document de travail du personnel 2019-8

\title{
Macroprudential Policy with Capital Buffers
}

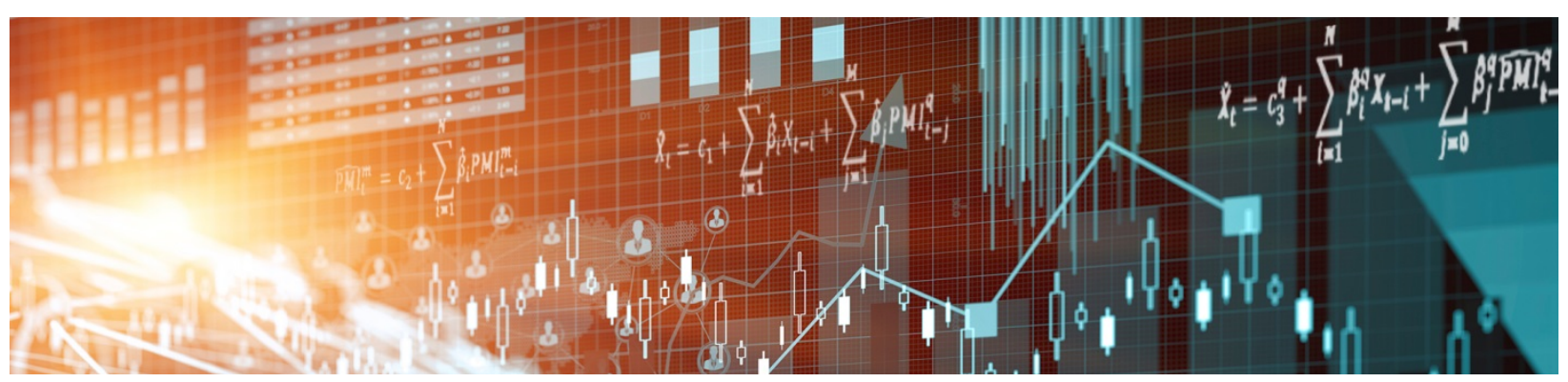

by Josef Schroth 
Bank of Canada Staff Working Paper 2019-8

February 2019

\title{
Macroprudential Policy with Capital Buffers
}

\author{
by \\ Josef Schroth \\ Financial Stability Department \\ Bank of Canada \\ Ottawa, Ontario, Canada K1A 0G9 \\ jschroth@bankofcanada.ca
}




\section{Acknowledgements}

For helpful comments and suggestions I am grateful to Thomas Carter, Mathias Drehmann, Martin Kuncl and seminar participants at the Bank for International Settlements. Part of this research was conducted while I was a Central Bank Research Fellow at the Bank for International Settlements. Any views expressed are my own and not necessarily those of the Bank of Canada. 


\begin{abstract}
This paper studies optimal bank capital requirements in a model of endogenous bank funding conditions. I find that requirements should be higher during good times such that a macroprudential "buffer" is provided. However, whether banks can use buffers to maintain lending during a financial crisis depends on the capital requirement during the subsequent recovery. The reason is that a high requirement during the recovery lowers bank shareholder value during the crisis and thus creates funding-market pressure to use buffers for deleveraging rather than for maintaining lending. Therefore, buffers are useful if banks are not required to rebuild them quickly.
\end{abstract}

Bank topics: Credit and credit aggregates; Financial stability; Financial system regulation and policies; Business fluctuations and cycles; Credit risk management; Lender of last resort

JEL codes: E13, E32, E44

\title{
Résumé
}

Dans cette étude, je cherche à déterminer le niveau optimal des exigences de fonds propres à l'aide d'un modèle dans lequel les conditions de financement des banques sont endogènes. J'arrive à la conclusion que ce niveau devrait être plus élevé lorsque la conjoncture est favorable de manière à créer un « volant » macroprudentiel. Toutefois, la mobilisation des volants par les banques pour maintenir leur offre de crédit inchangée en période de crise financière dépend des exigences de fonds propres au cours de la reprise subséquente. Il en est ainsi parce que des exigences élevées de fonds propres à ce moment-là ont pour effet d'abaisser la valeur actionnariale durant la crise, ce qui, sous l'effet des contraintes liées au financement de marché, incite les banques à se servir des volants pour se désendetter plutôt que pour maintenir l'offre de crédit. Il en découle que les volants sont utiles à condition que les banques ne soient pas tenues de les reconstituer rapidement.

Sujets : Crédits et agrégats du crédit; Stabilité financière ; Réglementation et politiques relatives au système financier; Cycles et fluctuations économiques ; Gestion du risque de crédit ; Fonction de prêteur de dernier ressort

Codes JEL : E13, E32, E44 


\section{Non-Technical Summary}

Following the recent financial crises in the United States and the European Union, there has been a concerted effort by policy makers to require banks to hold more capital. Higher minimum capital requirements reduce losses to stakeholders in case of bank failures but may constrain intermediation when it is most scarce-during financial crises. On the other hand, regulatory capital buffers do not constrain intermediation provided the bank is willing to constrain payouts instead. Buffers are macroprudential, rather than microprudential, because they are intended to guard against sudden decreases in intermediation activity throughout the economy rather than against losses from a bank's failure.

This paper develops a model of optimal bank capital regulation. Minimum requirements should be as low as possible while still discouraging moral hazard. I find that buffers during good times have small cost in terms of lower lending. Their benefit, in terms of stabilizing intermediation during crisis times, depends crucially on payout restrictions during crisis recovery times. When such restrictions are harsh, their anticipation effectively decreases banks' skin in the game during crisis times, thereby lowering banks' access to funding and forcing them to reduce intermediation. Therefore, the main result of the paper is that optimal capital buffers should be large on average but low in the aftermath of financial crises. 


\section{Introduction}

The recent financial crises in the United States and the European Union exposed taxpayers to potential losses from bank failures and significantly disrupted financial intermediation. A natural question arises from these experiences: Should regulators require banks to hold more capital and, if so, in what form? Higher minimum requirements reduce losses to stakeholders in case of bank failures but may constrain intermediation when it is most scarce-during financial crises. On the other hand, regulatory capital buffers do not constrain intermediation provided the bank is willing to constrain payouts instead.

This paper develops a model of optimal bank capital and derives implications for bank capital regulation. There is only one type of bank debt in the model, such that capital takes the form of equity, and only one bank asset, loans to firms. There are two key frictions. First, bank equity is costly in the sense that bank shareholders demand a higher return than holders of bank debt. Second, holders of bank debt are wary of potential bank moral hazard in the sense that they require that bank shareholder value is not too low relative to the size of the bank balance sheet.

Together, the two frictions create a challenging risk-management problem for the bank. On the one hand, when bank equity is too low, then banks are debt-funding constrained because of fear of bank moral hazard, and lending margins are high because of decreasing returns to scale at the firm level. On the other hand, banks hold costly equity—as a provision in case of low loan repayments—only if there is a strictly positive probability that they actually become funding-constrained. The two frictions therefore imply that banks lose access to the market for debt finance occasionally, at which point there is a credit crunch in the economy. 
I study optimal capital regulation in the model by comparing the competitiveequilibrium allocation with the constrained-efficient allocation. Specifically, I interpret the difference between these two allocations as due to optimal capital regulation. There are two general-equilibrium channels that can be exploited in a constrained-efficient allocation. First, it is feasible, in the sense of satisfying bank participation constraints, to require banks to hold more costly equity during times of high loan repayments as long as overall bank profitability is somewhat raised. Second, it is possible to allow low bank equity, and high bank leverage, during times of low loan repayments as long as bank profitability is significantly raised temporarily for a while in a way that satisfies the bank debt funding constraint. In that sense, regulation trades off small and permanent against large but temporary distortions when taking measures to stabilize loan supply over time.

The main result of the paper is that optimal regulation requires banks to hold more equity when loan supply is high, but also allows banks to hold very little equity when loan supply is low. It is crucial that banks are also allowed to rebuild equity slowly after loan supply has been low—otherwise, loan supply would become very low when banks have very little equity. The reason is that if banks were to anticipate that they would have to rebuild costly equity quickly, then they would have lower shareholder value and, because of increased moral hazard concerns, reduced access to debt funding when equity is low. ${ }^{1}$ In other words, regulation must take into account that it cannot stimulate loan supply when bank equity is low by setting an equity requirement that is lower than the one implicitly imposed by the market for debt funding. Optimal regulation also requires banks to increase loan supply somewhat more slowly during

\footnotetext{
${ }^{1}$ Hellmann et al. (2000) point out the relationship between costly bank equity and bank lending in a steady state, while Schroth (2016) analyzes the dynamic trade-off in a deterministic economy. This paper studies the dynamic trade-off in a stochastic economy with endogenous financial crises.
} 
a recovery from a credit crunch than they otherwise would. The resulting temporarily higher lending margins further raise bank dividend payout ratios during the time loan supply recovers, and further improves banks' access to debt funding during the time when loan supply is low. In that sense, when banks are offered a stake in the recovery from a credit crunch—through temporarily less onerous regulation and higher profit margins-then the credit crunch is less severe.

Three main policy implications can be derived from the analysis. First, minimum capital requirements should be as low as possible while still discouraging moral haz$\operatorname{ard}^{2}$ Second, any additional capital that a regulator wishes banks to hold should take the form of "capital buffers." The difference between a minimum requirement and a capital buffer is that banks are not forced to reduce the size of their balance sheet when they breach the latter. Specifically, banks may reduce equity payouts instead of deleveraging. Third, capital buffers that banks build up during good times are most effective in stabilizing lending during a financial crisis when banks are allowed to rebuild them slowly—while maintaining a high equity payout ratio—during the recovery from a financial crisis.

These policy implications can be compared with recent changes in recommendations for bank regulation under the Basel Accord (Basel Committee on Banking Supervision, 2010) denoted "Basel III." First, the analysis suggests that market-imposed capital requirements are lower during financial crises for given bank borrower default rates. Adherence to rigid microprudential capital requirements at all times may therefore not be optimal. In practice, giving banks some discretion in calculating risk-weighted assets during times of crisis can be justified for this reason-since bank margins are high when aggregate bank equity is low (for evidence and theory on

\footnotetext{
${ }^{2}$ This result simply follows from the insight in, for example, Alvarez and Jermann (2000) that debt constraints should not be "too tight."
} 
"regulatory forbearance," see Huizinga and Laeven, 2012; Repullo, 2013; Repullo and Suarez, 2013). Second, there should be a buffer on top of market-imposed capital requirements-augmenting voluntary bank loan loss provisioning - that can be used to stabilize lending when bank equity is low. However, no equity payouts are allowed when this buffer is being used. This buffer resembles the capital conservation buffer under Basel III. Third, there should be an additional buffer that can be used when the first one is depleted. It can be used for lending. It can also be used for dividend payouts—or, equivalently, it is "released"— but only once the first buffer has been rebuilt. This additional buffer resembles the countercyclical capital buffer (CCyB) under Basel III. In my model, it is crucial that the regulator raises bank future profitability temporarily during the time when banks use the additional buffer to pay out dividends. The reason is that otherwise dividend payouts in the face of low bank equity would threaten bank solvency. In practice, bank profitability could be supported by recapitalizations financed by taxes on bank lending. ${ }^{3}$

\subsection{Related literature}

Existing empirical work finds that financial crises are costly in terms of forgone output and generally lead to policy interventions that aim at restoring credit supply (Laeven and Valencia, 2013; Bernanke, 2018). Indeed, existing theoretical work suggests that interventions can improve welfare significantly because of the pivotal role that financial intermediaries play (Bebchuk and Goldstein, 2011; Philippon and Schnabl, 2013; Sandri and Valencia, 2013; Schroth, 2016). However, theoretical work also stresses the importance of ex ante measures, such as capital buffers, which reduce the need to rely

\footnotetext{
${ }^{3}$ The recapitalizations under the Troubled Asset Relief Program during the 2007-2009 US financial crisis were eventually repaid by participating financial institutions such that the cost of recapitalizations was partly passed on to clients-e.g., bank borrowers-during the recovery from the crisis.
} 
on ex post policy intervention (Lorenzoni, 2008; Martinez-Miera and Suarez, 2012; Begenau, 2014; Clerc et al., 2015). The literature that trades off ex post intervention and ex ante measures relates bank access to funding to the liquidation value of bank assets during a default (e.g., Jeanne and Korinek, 2013). For example, during the 2007-2008 US financial crisis, there was a run in the market for secured bank funding when concerns about bank solvency suddenly emerged. ${ }^{4}$ This paper contributes to this literature by relating the bank's decision to default to its future prospects. The approach is motivated by the fact that a defaulting bank loses its charter value, and the charter value depends (positively) on the bank's future prospects. Novel implications for bank regulation follow from this approach. ${ }^{5}$

\section{Model}

This section describes an infinite horizon economy in discrete time with time periods $t=0,1,2, \ldots$ There are aggregate productivity shocks $s_{t} \in S=\left\{s_{L}, s_{H}\right\} \subset \mathbb{R}_{++}$, where $\operatorname{Pr}\left(s_{t}=s_{L}\right)=\rho$ in each period $t=1,2, \ldots$ The initial state is given as $s_{0}$. Define the sets $S^{t}=S \times S^{t-1}$ for $t=1,2, \ldots$ where $S^{0}=\left\{s_{0}\right\}$. Let $s^{t}$ denote the history of productivity shocks up to period $t$ and the initial state, with $s^{0}=s_{0}$, and define the probability measure $\pi_{t}$ on $S^{t}$. Denote conditional probabilities by $\pi_{t}\left(s^{t+\tau} \mid s^{t}\right)$ for any $t$ and $\tau=1,2, \ldots$. There is a measure one of identical short-lived firms producing a consumption good and investing using external funds obtained from a measure one of identical banks. Finally, risk-neutral households, also of measure one,

\footnotetext{
${ }^{4}$ The observed run on the repurchase market was characterized by a sudden increase in haircuts (Gorton and Metrick, 2012). Sudden concerns about the solvency of banks reflect a fear that the liquidation value of a given bank asset might be lower when the bank owning the asset defaults.

${ }^{5}$ Indeed, recent regulatory reforms often reflect concerns about inefficiently high bank risk-taking in the run-up to financial crises while my approach focuses on inefficiently low bank risk-taking during financial crises. Section 4.1.1 provides further discussion.
} 
value consumption and are endowed with one unit of labor each, which they supply inelastically. Households and banks trade one-period non-contingent bonds with each other.

\subsection{Firms}

Firms live for one period. They have access to a production technology that turns $k$ units of the consumption good in period $t$ and $l$ units of labor in period $t+1$ into $F\left(k, l ; s_{t+1}\right)=s_{t+1} k^{\alpha} l^{1-\alpha}+(1-\delta) k$ units of the consumption good in period $t+1$, where aggregate productivity $s_{t+1}$ is realized at the beginning of period $t+1$, before $l$ is chosen, and where $\delta \in(0,1)$ is the depreciation rate. It is assumed that firms cannot sell bonds and do not have any internal funds such that they must borrow from a bank to fund capital investment. A firm that is born at the end of period $t$ in state $s^{t}$ produces in period $t+1$ and maximizes its expected profit subject to solvency in each state of the world:

$$
\max _{k \geq 0} \sum_{s_{t+1} \in S} \pi_{t}\left(s^{t+1} \mid s^{t}\right)\left[\max _{l}\left\{s_{t+1} k^{\alpha} l^{1-\alpha}+(1-\delta) k-w_{t+1}\left(s^{t+1}\right) l\right\}-R_{t+1}\left(s^{t+1}\right) k\right]
$$

subject to $\max _{l}\left\{s_{t+1} k^{\alpha} l^{1-\alpha}+(1-\delta) k-w_{t+1}\left(s^{t+1}\right) l\right\}-R_{t+1}\left(s^{t+1}\right) k \geq 0$ for each $s_{t+1} \in$ $S$. For given wages $w_{t+1}\left(s^{t+1}\right)$ and bank lending returns $R_{t+1}\left(s^{t+1}\right)$, the optimal firm labor input and capital investment choices are characterized as follows:

$$
\begin{aligned}
& w_{t+1}\left(s^{t+1}\right)=(1-\alpha) s_{t+1} k^{\alpha} l^{-\alpha}, \\
& R_{t+1}\left(s^{t+1}\right)=\alpha s_{t+1} k^{\alpha-1} l^{1-\alpha}+1-\delta, \text { for each } s_{t+1} \in S .
\end{aligned}
$$


It is assumed that firm profits accrue to households. Note that profits are zero for any realization of $s_{t+1}$ because of constant returns to scale.

\subsection{Households}

Households are risk-neutral and value consumption. They are endowed with one unit of labor in period $t=1,2, \ldots$ and $w_{0}$ units of the consumption good in period zero. Households discount future consumption using the subjective discount factor $\beta<1$. Note that households are willing to trade the one-period non-contingent bond in finite quantity as long as its price is equal to $\beta$, implying a gross return of $1 / \beta$ in an equilibrium of the model.

\subsection{Banks}

Banks are risk-neutral and value dividends $d_{t}\left(s^{t}\right)$. Let $\ell_{t+1}\left(s^{t}\right)$ denote bank lending to firms in period $t=0,1,2, \ldots$ Both dividend and lending choices are constrained to be non-negative. Banks face budget constraints as follows:

$$
\begin{aligned}
d_{t}\left(s^{t}\right)+\ell_{t+1}\left(s^{t}\right)+\beta b_{t+1}\left(s^{t}\right) & \leq R_{t}\left(s^{t}\right) \ell_{t}\left(s^{t-1}\right)+b_{t}\left(s^{t-1}\right), \text { for } t=1,2, \ldots, \text { and } \\
d_{0}\left(s_{0}\right)+\ell_{1}\left(s_{0}\right)+\beta b_{1}\left(s_{0}\right) & \leq a_{0},
\end{aligned}
$$

where $b_{t+1}\left(s^{t}\right)$ denotes a bank's purchase of one-period non-contingent bonds at price $\beta$ for $t=0,1,2, \ldots$ and $a_{0}>0$ denotes given initial bank equity. For $t=1,2, \ldots$ define bank equity as $a_{t}\left(s^{t}\right)=R_{t}\left(s^{t}\right) \ell_{t}\left(s^{t-1}\right)+b_{t}\left(s^{t-1}\right)$.

Banks discount future dividends using the discount factor $\beta<1$. However, it is assumed that a bank enters an "accident" state at the beginning of each period with constant probability $1-\gamma / \beta>0$. When banks experience an accident, they pay all eq- 
uity—i.e., all loan repayments net of debt—into an "accident fund" and exit the economy. The fund immediately distributes the collected equity among a measure $1-\gamma / \beta$ of new banks that enter the economy. The assumption captures corporate governance problems and implies that banks effectively discount dividends using the lower discount factor $\gamma<\beta$ such that the value of a bank is $V_{0}=\sum_{t=0}^{\infty} \gamma^{t} \sum_{s^{t} \in S^{t}} d_{t}\left(s^{t}\right) \pi_{t}\left(s^{t}\right)$.

However, banks will generally not set dividends as high as possible because the timing of bank dividends determines a bank's incentive to engage in moral hazard, which in turn affects the bank's access to external funding. In particular, bank creditors (i.e., households) are willing to provide external funding to a bank as long as the bank values the future dividends it expects to enjoy more than a fraction $\theta \in(0,1)$ of its lending. The reason is that bank assets $\ell_{t+1}\left(s^{t}\right)$ are not liquid and diminish by fraction $\theta$ unless monitored by a bank. A bank could thus extract $\theta \ell_{t+1}\left(s^{t}\right)$ by defaulting and threatening creditors not to monitor their assets. This consideration is captured by the following no-default constraint that needs to be satisfied in every period $t=0,1,2, \ldots$ in which the bank wishes to make use of external funding: ${ }^{6}$

$$
\sum_{\tau=1}^{\infty} \gamma^{\tau} \sum_{s^{t+\tau}} \pi_{t}\left(s^{t+\tau} \mid s^{t}\right) d_{t+\tau}\left(s^{t+\tau}\right) \geq \theta \ell_{t+1}\left(s^{t}\right)
$$

The problem of a bank is thus to choose lending and bonds to maximize its value at date zero subject to (4), (5), (6) and dividend non-negativity. Let $\beta^{t} \pi_{t}\left(s^{t}\right) \psi_{t}\left(s^{t}\right)$ be the multiplier on the no-default condition (6) in period $t$, when $\ell_{t+1}\left(s^{t}\right)$ is chosen. It determines the change in the value of the bank's internal funds (equity) when the bank

\footnotetext{
${ }^{6}$ The amount $\theta \ell_{t+1}\left(s^{t}\right)$ that banks can extract by defaulting may exceed their external funding $-b_{t+1}\left(s^{t}\right)$. The idea is that bank creditors would receive all bank assets in case of a bank default even if their "liquidation value" $\theta \ell_{t+1}\left(s^{t}\right)$ exceeds liabilities. When banks fund lending exclusively with equity, such that $b_{t+1}\left(s^{t}\right) \geq 0$, then condition (6) can be interpreted as providing incentives for the bank to keep its lending portfolio. Then $\theta \ell_{t+1}\left(s^{t}\right)$ would be the payment the bank could extract from any acquirer of its portfolio (for example, a household).
} 
loses access to external funding-i.e., when the bank is constrained and cannot sell additional bonds. Let the value of internal funds be $\beta^{t} \pi_{t}\left(s^{t}\right) \lambda_{t}\left(s^{t}\right)$, i.e., the multiplier on the bank budget constraints. Then the first-order condition for bank lending $\ell_{t+1}\left(s^{t}\right)$ can be written as follows:

$$
\theta \psi_{t}\left(s^{t}\right)=\gamma \sum_{s_{t+1}} \pi_{t}\left(s^{t+1} \mid s^{t}\right)\left[\lambda_{t+1}\left(s^{t+1}\right)\left(R_{t+1}\left(s^{t+1}\right)-\frac{1}{\beta}\right)\right] .
$$

Equation (7) says that banks are profitable, after adjusting their income for its riskiness, only at times when they lose access to external funding. The reason is that banks are competitive and would immediately compete away any risk-adjusted profit margin if their creditors would allow them to increase leverage. The model thus predicts that lending spreads are elevated during financial crises (Muir, 2017).

The first-order condition for bonds is given by

$$
\lambda_{t}\left(s^{t}\right)=\sum_{s_{t+1}} \lambda_{t+1}\left(s^{t+1}\right) \pi_{t}\left(s^{t+1} \mid s^{t}\right) .
$$

Let $\beta^{t} \pi_{t}\left(s^{t}\right) \mu_{t}\left(s^{t}\right)$ denote the multiplier on dividend non-negativity. Then the firstorder condition for dividends can be written as

$$
\lambda_{t}\left(s^{t}\right)=\left(\frac{\gamma}{\beta}\right)^{t}+\mu_{t}\left(s^{t}\right)+\sum_{\tau=0}^{t-1}\left(\frac{\gamma}{\beta}\right)^{t-\tau} \psi_{\tau}\left(s^{\tau}\right)
$$

where $s^{\tau}$ denote sub-histories of $s^{t}$. The assumption that banks are more impatient than other participants in the bond market, i.e., $\gamma<\beta$, implies that (6) will occasionally bind, as Proposition 1 shows.

Proposition 1. The bank no-default condition binds occasionally.

Proof. The first-order condition for bank bond holdings implies that the return on 
equity $\lambda_{t}$ converges almost surely. Hence, if the bank no-default constraint (6) were not binding occasionally, then $\psi_{t}=0$ almost surely and thus $\lambda_{t}-\mu_{t} \rightarrow 0$ almost surely. But then dividends are zero almost surely, implying that (6) is in fact binding almost surely.

Bank equity is valuable because it can be used to relax the bank no-default constraint and allow the bank to lend more and to attract more external funding at exactly those times when bank lending is profitable. Each bank is aware that low realizations of the aggregate shock lower equity of all other banks and increase the probability that other banks will lose access to external funding in the current or some future period. For this reason, each bank regards lending income as risky and extends lending only up to the point where their risk-adjusted profitability drops to zero. ${ }^{7}$ Banks thus engage in loan loss provisioning as a result of the "last bank standing effect" (Perotti and Suarez, 2002).

Equations (8) and (9) reveal that the bank's risk-management problem has both a forward-looking and a backward-looking component. On the one hand, internal funds (equity) in the current period can be used to reduce leverage. Lower leverage reduces the probability of losing access to market funding and being forced to cut dividends, potentially to zero, in future periods. On the other hand, internal funds in the current period can be used to pay dividends and thus increase access to market funding in all preceding periods through relaxing market-imposed no-default constraints. The model in this paper thus gives an example of how financial intermediaries evaluate risk differently compared with the representative household (He and Krishnamurthy, 2013; Adrian, Etula, and Muir, 2014). This difference in risk perception plays a crucial

\footnotetext{
${ }^{7}$ The bond market is incomplete exogenously in this paper. Lorenzoni (2008) and Rampini and Viswanathan $(2010,2018)$ show how contracting frictions limit bank risk management even if a complete set of contingent securities is potentially available.
} 
role in shaping the implications of this paper for financial regulation.

\subsection{Competitive equilibrium}

Spot markets for labor, contingent bank loans, and one-period non-contingent bonds open in every period $t$. In every period $t$, the wage $w_{t}$ clears the labor market and the returns on loans $R_{t+1}$ clear the market for lending. Definition 1, below, characterizes a competitive equilibrium in terms of lending returns, wages, and bank actions.

Definition 1. A competitive equilibrium is characterized by lending returns $\left\{R_{t+1}\left(s^{t+1}\right)\right\}_{t=0,1,2, \ldots}$, wages $\left\{w_{t}\left(s^{t}\right)\right\}_{t=1,2, \ldots}$, as well as bank actions $\left\{d_{t}\left(s^{t}\right), b_{t+1}\left(s^{t}\right), \ell_{t+1}\left(s^{t}\right)\right\}_{t=0,1,2, \ldots}$ such that (i) bank actions obey first-order conditions (7), (8), and (9), and (ii) lending returns satisfy $R_{t+1}\left(s^{t+1}\right)=s_{t+1} \alpha \ell_{t+1}^{\alpha-1}\left(s^{t}\right)+1-\delta$ and wages satisfy $w_{t+1}\left(s^{t+1}\right)=s_{t+1}(1-\alpha) \ell_{t+1}^{\alpha}\left(s^{t}\right)$ for $t=0,1,2, \ldots$

\subsection{Deterministic steady state}

Suppose $s_{L}=s_{H}=1$ such that the economy does not experience any stochastic fluctuations. Define first-best lending as follows:

$$
K_{F B}=\left[\frac{\alpha}{1 / \beta-(1-\delta)}\right]^{\frac{1}{1-\alpha}}
$$

Lemma 1 shows that banks provide less than the first-best amount of lending in steady state. The reason is that banks view equity as costly relative to external funding. The required return on bank lending is given by $R_{C E}=1 / \beta+\theta(\beta-\gamma) / \beta \gamma$. This return is higher than the return on external funding, $1 / \beta$, but lower than the required return on 
internal funds, $1 / \gamma$, for $\theta<1.8$

Lemma 1. Steady-state lending in the deterministic case in competitive equilibrium is given as follows:

$$
K_{C E}=\left[\frac{\alpha}{1 / \beta+\theta(\beta-\gamma) / \beta \gamma-(1-\delta)}\right]^{\frac{1}{1-\alpha}} .
$$

Proof. Banks pay strictly positive dividends in a steady state of the competitive equilibrium such that $\mu_{t}=0$. It follows from equations (8) and (9) that $\psi_{t}=\frac{\beta-\gamma}{\gamma} \lambda_{t}$ in a steady state. Further, banks are always borrowing-constrained due to their relative impatience. The amount of steady state lending in a competitive equilibrium then follows from equation (7).

\section{Macroprudential capital requirements}

This section analyzes the model analytically. I will first discuss how the no-default constraint (6) can be interpreted as a (market-imposed) bank capital requirement. Then, I will present first-order conditions that characterize the second-best allocation and imply a rationale for macroprudential capital regulation in the model economy.

\footnotetext{
${ }^{8}$ When banks can hold creditors up to the full amount of lending, i.e., if $\theta=1$, then only equity is used to fund bank lending and the required return on bank lending becomes $1 / \gamma$. In this case, the bank no-default constraint (6) can be interpreted as a no-abandonment or no-sale condition. It keeps the bank from abandoning or selling its assets and extracting $\ell_{t+1}\left(s^{t}\right)$ from the acquirer in exchange for monitoring them and thus facilitating their liquidation.
} 


\subsection{Bank no-default constraint and capital requirements}

Let $a_{t}$ denote bank equity and let $\Pi_{t}$ denote the value of a bank's charter net of equity; then

$$
\begin{aligned}
a_{t}\left(s^{t}\right)= & R_{t}\left(s^{t}\right) \ell_{t}\left(s^{t-1}\right)+b_{t}\left(s^{t-1}\right) \quad \text { for } t=1,2, \ldots \text { and } a_{0} \text { given, } \\
\Pi_{t}\left(s^{t}\right)= & \sum_{\tau=1}^{\infty} \gamma^{\tau} \sum_{s^{t+\tau} \in S^{t+\tau}}\left[R_{t+\tau}\left(s^{t+\tau}\right)-\frac{1}{\gamma}\right] \ell_{t+\tau}\left(s^{t+\tau-1}\right) \pi_{t}\left(s^{t+\tau} \mid s^{t}\right) \\
& +\sum_{\tau=1}^{\infty} \gamma^{\tau} \sum_{s^{t+\tau} \in S^{t+\tau}} \frac{\gamma-\beta}{\gamma} b_{t+\tau}\left(s^{t+\tau-1}\right) \pi_{t}\left(s^{t+\tau} \mid s^{t}\right) .
\end{aligned}
$$

Note that the first term in $\Pi_{t}$ is the present value of pure profits where the bank's own discount factor is used rather than the bond market discount factor $\beta$. Since $\gamma<\beta$, this term is lower for given lending returns than it is when bank profits are discounted using bond prices. The second term reflects the fact that usage of external funding, $b_{t+\tau}\left(s^{t+\tau-1}\right)<0$, is a way for the bank to increase its value. That is, there is a benefit for the bank from front-loading dividends and from back-loading debt repayments as a result of impatience. When bank budget constraints are used to substitute out dividends, the value of a bank at time $t$ can be expressed as $V_{t}\left(s^{t}\right)=a_{t}\left(s^{t}\right)+\Pi_{t}\left(s^{t}\right)$. The no-default constraint (6) can then be reformulated as follows:

$$
\gamma \sum_{s_{t+1} \in S} a_{t+1}\left(s^{t+1}\right) \pi_{t}\left(s^{t+1} \mid s^{t}\right) \geq \theta \ell_{t+1}\left(s^{t}\right)-\gamma \sum_{s_{t+1} \in S} \Pi_{t+1}\left(s^{t+1}\right) \pi_{t}\left(s^{t+1} \mid s^{t}\right) .
$$

With bank capital defined as expected equity, (14) gives a capital requirement that depends on the expected present value of bank future profits. This capital requirement is microprudential in the sense that its purpose is to guarantee the solvency of the bank only. For example, if the value of the bank does not exceed its equity, then permissible leverage is given by $1 / \theta$. If the bank is expected to have positive future profits, then it 
is allowed to have higher leverage because future profits serve as "skin in the game."

It is important to note that microprudential capital requirements are low in this economy, in the sense that banks often hold capital (equity) well above the requirement stipulated by equation (14), implying that equation (14) will bind only occasionally. The reason is that banks seek to protect their charter value; that is, they risk-adjust income from lending to avoid low equity (and binding capital requirements) in states where the return on lending is high (loan loss provisioning). In that sense, marketimposed capital requirements already induce prudent behavior to some extent. Section 3.2 asks whether this extent is sufficient or whether additional macroprudential capital regulation is necessary.

The remainder of the paper studies second-best capital requirements, i.e., changes in the allocation of bank equity and lending that increase lending to firms weighted by the marginal product of capital subject to the market-imposed capital requirement (14). I interpret the difference between the second-best allocation and the competitiveequilibrium allocation-in which banks are only constrained by microprudential regulation implied by (14)—as resulting from macroprudential capital regulation. I then discuss how macroprudential regulatory tools used in practice might be combined toward implementing the optimal macroprudential regulation, or second-best allocation, that is identified in the paper.

\subsection{Optimal capital regulation}

The capital requirement (14) gives rise to a pecuniary externality, in the sense of Greenwald and Stiglitz (1986). Hence, an exclusive reliance on loan loss provisioning motivated by market discipline may leave some inefficiencies in this economy unaddressed.

The reason is that future asset prices, i.e., future lending returns $\left\{R_{t+\tau}\left(s^{t+\tau}\right)\right\}_{\tau=1,2, \ldots}$, 
enter (14) through expected future profits given by equation (13) at each point in time $t=0,1,2, \ldots$. A constrained social planner can therefore affect capital requirements, and thus permissible bank leverage, by affecting these future asset prices (as in Schroth, 2016). This paper focuses on how a constrained social planner can stabilize aggregate lending in the economy over time, by exploiting the pecuniary externality, and thus improve upon self-interested (competitive) individual provisioning by banks.

Because banks consider equity to be costly, relative to external funding, it is necessary to impose bank participation constraints in periods $t=0,1,2, \ldots$ :

$$
V_{t}\left(s^{t}\right) \equiv d_{t}\left(s^{t}\right)+\sum_{\tau=1}^{\infty} \gamma^{\tau} \sum_{s^{t+\tau}} \pi_{t}\left(s^{t+\tau} \mid s^{t}\right) d_{t+\tau}\left(s^{t+\tau}\right) \geq a_{t}\left(s^{t}\right) \quad \text { for all } s^{t} \in S^{t}
$$

Condition (15) ensures that banks prefer continuing to be banks rather than liquidating their assets. Note that the bank participation constraint is equivalent to $\Pi_{t}\left(s^{t}\right) \geq$ 0 . Condition (15) requires that the future profits that banks expect to earn are nonnegative. The condition would never bind in a competitive equilibrium because banks are free to reduce lending and increase dividends. To see why it might be binding in a constrained-efficient—or second-best—allocation, consider the case in which bank lending is first best and bank debt is zero, such that the first term in $\Pi_{t}$ is negative while the second is zero. A second-best allocation will thus allow for bank leverage or bank rents or both to discourage banks from liquidating themselves (recall also the discussion in Section 2.5).

Definition 2. The second-best allocation is given by sequences of dividends $\left\{D_{t}\left(s^{t}\right)\right\}_{s^{t} \in S^{t}, t \geq 0}$, bank bond holdings $\left\{B_{t+1}\left(s^{t}\right)\right\}_{s^{t} \in S^{t}, t \geq 0}$ and bank lending $\left\{K_{t+1}\left(s^{t}\right)\right\}_{s^{t} \in S^{t}, t \geq 0}$ such that social welfare

$$
\mathcal{W} \equiv D_{0}\left(s_{0}\right)+\sum_{t=1}^{\infty} \beta^{t} \sum_{s^{t} \in S^{t}}\left[D_{t}\left(s^{t}\right)+w_{t}\left(s^{t}\right)\right] \pi_{t}\left(s^{t}\right)
$$


is maximized subject to initial bank equity $a_{0}$, prices for labor and loans

$$
\begin{aligned}
& w_{t}\left(s^{t}\right)=s_{t}(1-\alpha) K_{t}\left(s^{t-1}\right)^{\alpha}, \\
& R_{t}\left(s^{t}\right)=s_{t} \alpha K_{t}\left(s^{t-1}\right)^{\alpha-1}+1-\delta,
\end{aligned}
$$

market-imposed no-default constraints

$$
\sum_{\tau=1}^{\infty} \gamma^{\tau} \sum_{s^{t+\tau}} \pi_{t}\left(s^{t+\tau} \mid s^{t}\right) D_{t+\tau}\left(s^{t+\tau}\right) \geq \theta K_{t+1}\left(s^{t}\right)
$$

bank budget constraints

$$
\begin{aligned}
D_{t}\left(s^{t}\right)+K_{t+1}\left(s^{t}\right)+\beta B_{t+1}\left(s^{t}\right) & \leq R_{t}\left(s^{t}\right) K_{t}\left(s^{t-1}\right)+B_{t}\left(s^{t-1}\right), \text { for } t=1,2, \ldots, \text { and } \\
D_{0}\left(s_{0}\right)+K_{1}\left(s_{0}\right)+\beta B_{1}\left(s_{0}\right) & \leq a_{0},
\end{aligned}
$$

dividend non-negativity, $D_{t}\left(s^{t}\right) \geq 0$, as well as the bank participation constraint

$$
D_{t}\left(s^{t}\right)+\sum_{\tau=1}^{\infty} \gamma^{\tau} \sum_{s^{t+\tau}} \pi_{t}\left(s^{t+\tau} \mid s^{t}\right) D_{t+\tau}\left(s^{t+\tau}\right) \geq R_{t}\left(s^{t}\right) K_{t}\left(s^{t-1}\right)+B_{t}\left(s^{t-1}\right) \quad \text { for all } s^{t} \in S^{t} .
$$

In a second-best allocation, the no-default constraint can be relaxed by increasing future profits. However, while an increase in future bank profits mitigates a severe credit crunch, it also creates socially costly distortions in future bank lending.

\subsection{Analysis of the second-best allocation}

Before continuing to the numerical part of the paper, first-order conditions that the second-best allocation must satisfy are discussed. Let $\beta^{t} \pi_{t}\left(s^{t}\right) \psi_{t}\left(s^{t}\right)$ be the multiplier on the bank no-default constraint, $\beta^{t} \pi_{t}\left(s^{t}\right) \lambda_{t}\left(s^{t}\right)$ be the multiplier on the bank 
budget constraint, $\beta^{t} \pi_{t}\left(s^{t}\right) \eta_{t}\left(s^{t}\right)$ be the multiplier on the participation constraint, and $\beta^{t} \pi_{t}\left(s^{t}\right) \mu_{t}\left(s^{t}\right)$ the multiplier on dividend non-negativity. The first-order conditions for bonds and dividends can be combined as follows:

$$
\lambda_{t}\left(s^{t}\right)=1+\sum_{s_{t+1}} \mu_{t+1}\left(s^{t+1}\right) \pi_{t}\left(s^{t+1} \mid s^{t}\right)+\sum_{\tau=0}^{t}\left(\frac{\gamma}{\beta}\right)^{t+1-\tau}\left[\psi_{\tau}\left(s^{\tau}\right)+\eta_{\tau}\left(s^{\tau}\right)\right]
$$

where the terms $s^{\tau}$ denote sub-histories of $s^{t}$. Equation (16) shows that the return on bank equity is forward-looking as well as backward-looking. The constrained planner values current equity more if it is more likely that equity will be scarce in future periods, as indicated by binding dividend non-negativity constraints in the next period. However, the constrained planner also internalizes how higher equity in the current period can be used to increase the current dividend and thus relaxes bank no-default and participation constraints in all previous periods. Note that this intuition is almost the same as that in Section 2.3 (the bank participation constraint is ignored in Section 2.3 because it is satisfied by definition in competitive equilibrium). The difference is that the constrained planner is not impatient with respect to dividends and thus tends to value bank equity more highly. However, the bank participation constraint keeps the planner from back-loading dividends too much and from building up too much equity. The reason is that higher levels of equity necessitate higher rents from bank lending since the planner must deliver the return on bank equity $1 / \gamma$.

The first-order condition for bank lending reveals that the second-best allocation may feature an excess risk premium on bank lending even if banks have further access to external funding, i.e., even if the no-default constraint does not bind such that 
$\psi_{t}\left(s^{t}\right)=0$

$$
\begin{aligned}
\theta \psi_{t}\left(s^{t}\right) & +\beta \sum_{s_{t+1}}\left[\lambda_{t+1}\left(s^{t+1}\right)-\eta_{t+1}\left(s^{t+1}\right)-1\right] \alpha(1-\alpha) s_{t+1} K_{t+1}\left(s^{t}\right)^{\alpha-1} \pi_{t}\left(s^{t+1} \mid s^{t}\right) \\
= & \beta E_{t}\left[\left(\lambda_{t+1}-\eta_{t+1}\right)\left(R_{t+1}-\frac{1}{\beta}\right)\right] .
\end{aligned}
$$

That the second term on the left-hand side of equation (17) is non-negative can be seen by writing the first-order condition for dividends as follows:

$$
\lambda_{t+1}\left(s^{t+1}\right)-\eta_{t+1}\left(s^{t+1}\right)-1=\mu_{t+1}\left(s^{t+1}\right)+\sum_{\tau=1}^{t}\left(\frac{\gamma}{\beta}\right)^{t+1-\tau}\left[\psi_{\tau}\left(s^{\tau}\right)+\eta_{\tau}\left(s^{\tau}\right)\right],
$$

which is non-negative for all $s_{t+1}$. Excess returns enjoyed by banks therefore have a forward- and a backward-looking component. On the one hand, when the dividend non-negativity constraint is binding in the following period, then bank returns increase, which increases bank equity in that period and makes dividend non-negativity constraints bind less. On the other hand, when no-default or participation constraints have been binding in the past, bank returns increase, relaxing those constraints by increasing banks' ability to increase dividends in subsequent periods.

In summary, the intuition is as follows. When the no-default constraint binds, lending is severely reduced in the economy and excess lending returns shoot up. As a result, the value of bank internal funds increases, and this increase is long-lived by equation (17). This in turn leads to higher excess returns over a number of periods, increasing expected bank future profits immediately. The result is that the no-default constraint is being relaxed such that lending returns shoot up by less, at the social cost of somewhat higher lending returns over a number of future periods. That is, in a second-best allocation, the scarcity of bank lending is smoothed out over time. 


\subsubsection{Deterministic steady state}

Analyzing the second-best allocation in deterministic steady state reveals that the trade-offs faced by the constrained planner are dynamic rather than static. Indeed, Lemma 2 shows that the second-best allocation is identical to the competitive-equilibrium allocation in steady state of the deterministic economy. ${ }^{9}$

Lemma 2. Steady-state lending in the deterministic case in the second best is the same as in competitive equilibrium.

Proof. The bank participation constraint does not bind strictly because there is no benefit from having precautionary equity buffers in the deterministic case. Then multipliers are constant and satisfy $\psi=(\lambda-1)(\beta-\gamma) / \gamma$ by equation (16). The second-best amount of bank lending can then be obtained from equation (17) as a function of the value of bank equity as follows:

$$
K_{S B}(\lambda)=\left[\frac{\alpha(1-(1-\alpha)(\lambda-1) / \lambda)}{1 / \beta+\theta(\beta-\gamma) / \beta \gamma(\lambda-1) / \lambda-(1-\delta)}\right]^{\frac{1}{1-\alpha}} .
$$

For the bank participation constraint to hold, bank lending must be lower than $K_{C E}$ because the bank participation constraint binds weakly in a deterministic steady state of the competitive equilibrium. Hence, it must be the case that $K_{S B}(\lambda) \leq K_{C E}$. Because $\gamma<\beta$, the effect of initially scarce bank equity on the steady-state value of bank equity decays geometrically by equation (16). The value of bank equity in steady state therefore depends only on the multiplier on the no-default constraint in steady state.

\footnotetext{
${ }^{9}$ This is not the case when $\gamma=\beta$, since then the constrained planner would backload distortionary rents in a way that lowers the steady-state level of bank lending in the deterministic economy (see Schroth, 2016). $K_{S B}(\lambda)$ and $\lambda$ in the proof of Lemma 2 are not continuous as $\gamma \nearrow \beta$ because the nodefault constraint is slack in steady state when $\gamma=\beta$. The value of equity is decreasing when $\gamma<\beta$ and constant if $\gamma=\beta$.
} 
As a result, $K_{S B}(\lambda)=K_{C E}$ and

$$
\lambda=1+\frac{1}{1-\alpha} \frac{\theta(\beta-\gamma) / \beta \gamma}{1 / \beta+\theta(\beta-\gamma) / \beta \gamma-(1-\delta)} .
$$

\section{Numerical analysis}

This section analyzes the model numerically. Table 1 summarizes the choices of model parameter values used in this section. The choice of consumer discount factor $\beta$ implies an annual risk-free interest rate of around 6 percent. The depreciation rate and capital income share are set to 12 percent and 35 percent, respectively. The choice for $\theta$ implies a market-imposed capital requirement of 10 percent in normal times, when bank future profits are zero. ${ }^{10}$ The parameters characterizing the productivity shock process are chosen to allow the model to generate large crises. The economy experiences a "financial crisis" in period $t$ if the bank "lending gap"—the difference between first-best lending $K_{F B}$ and actual lending-is 5 percent or higher. The parameter $\gamma$ that determines the bank's relative cost of equity is set such that the economy spends around 6 percent of the time in a financial crisis (see Figure 1). ${ }^{11}$

In Section 3 it was shown that when the bank no-default condition binds in a second-best allocation, then lending returns are elevated for some time. Elevated future lending returns increase bank future profits and relax the no-default condition in the current period. The economic impact of a credit crunch, during which banks are forced to reduce lending due to insufficient access to external funding, is therefore

\footnotetext{
${ }^{10}$ The ratio of total equity to total assets for banks in the United States has been tending to increase over time and has been stable around 11 percent since 2010.

${ }^{11} \mathrm{~A}$ richer version of the model is calibrated in Moyen and Schroth (2018).
} 
Table 1: Model parameter values

\begin{tabular}{c|cl}
\hline \hline parameter & value & target \\
\hline$\beta$ & 0.94 & risk-free interest rate \\
$\gamma$ & 0.93 & crisis frequency \\
$\delta$ & 0.12 & average replacement investment \\
$\alpha$ & 0.35 & capital income share \\
$\theta$ & 0.10 & average bank leverage \\
$\left(z_{L}, z_{H}, \rho\right)$ & $(0.8,1.05,0.2)$ & several large crises
\end{tabular}

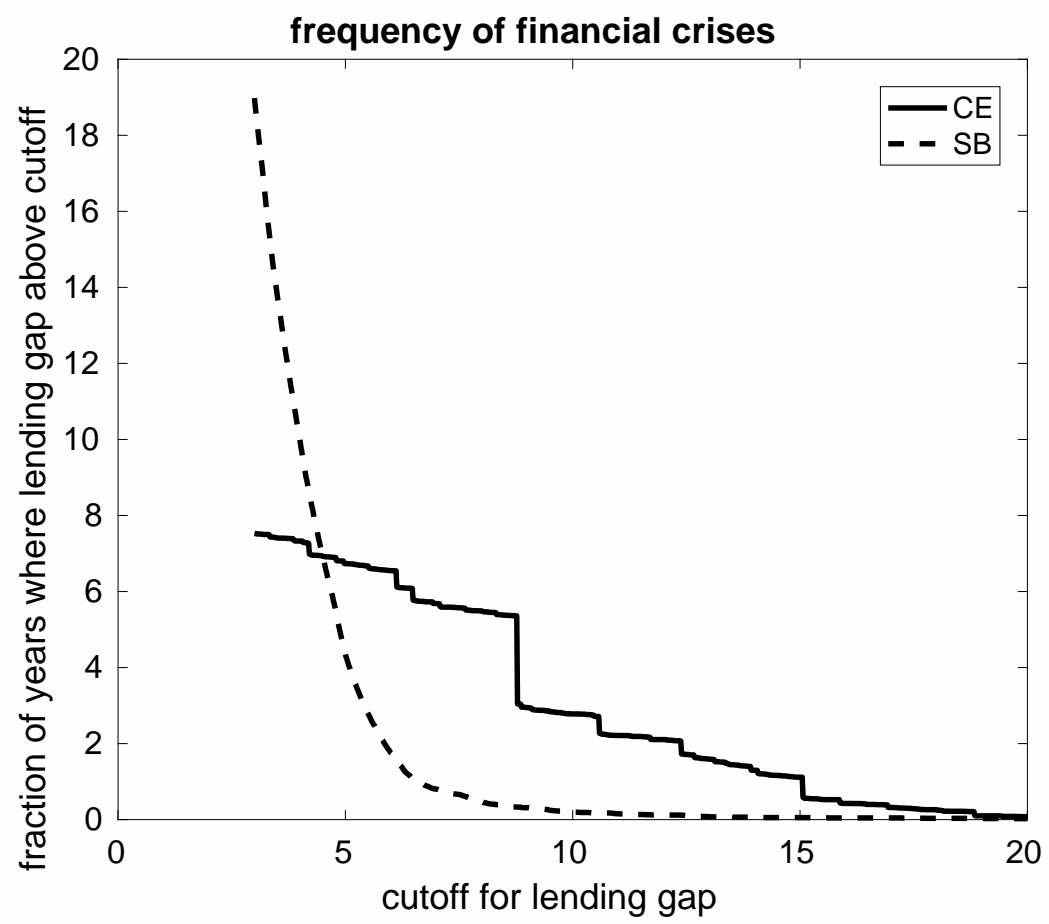

Figure 1: Frequency of low lending in a stochastic steady state (average over 30,000 simulated periods) in laissez-faire competitive-equilibrium allocation (CE) and second-best allocation (SB). 
mitigated. However, granting future profits to banks creates economic distortions such that a second-best allocation would also require banks to hold more equity on average. The idea is to limit use of an increase in future profits to the most severe credit crunches. As a result, banks are asked to increase their loan loss provisioning and can withstand more adverse shocks before the economy enters a credit crunch. On the rare occasions when the economy does enter a credit crunch despite higher provisioning, lending is stabilized by increasing bank future profits.

Figure 2 compares the second-best allocation with the competitive-equilibrium allocation for a given sequence of shocks. In particular, the high shock occurs between successive occurrences of the low shock for 1,2, and 4 times, respectively. Note that the high shock occurs sufficiently many times before each occurrence of low shocks for the economy to reach normal times, during which bank future profits are zero. Figure 2(a) shows that banks in competitive equilibrium hold a voluntary capital buffer of 2.75 percent. A constrained planner would require an additional buffer of 3 percent such that bank capital in the second-best allocation during normal times reaches 15.75 percent.

Bank lending during normal times is lower in the second-best allocation than it is in competitive equilibrium, as can be seen in Figure 2(b). The reason is that banks must be compensated with a higher expected return on lending when they are required to hold additional capital buffers because of the relatively higher cost of capital compared with external funding. However, bank lending is stabilized significantly in the second-best allocation compared with the competitive equilibrium. The reason is that the constrained planner can increase bank future profits at relatively low cost to offset decreases in bank equity whenever low-productivity shocks occur. The planner can deliver future profits at low cost to banks because the planner smooths out 
the associated economic distortions over time. That is, in contrast to the competitive equilibrium, the second-best allocation delivers bank future profits by increasing longterm lending returns somewhat rather than increasing short-term lending returns a lot. Bank lending thus drops by less during financial crises, but it also recovers more slowly during the time banks are allowed to earn their future profits.

Figure 3 shows that expected excess returns are positive in normal times to compensate banks for the cost of capital buffers. Lending returns are more smoothed out in the second-best allocation; returns shoot up by less since financial crises are much less severe, but they stay elevated for longer to deliver increases in bank future profits more cheaply. During a financial crisis, lending returns shoot up sharply in competitive equilibrium, but banks are still forced to deleverage and reduce their reliance on external funding drastically. In contrast, banks increase their reliance on external funding during a financial crisis in the second-best allocation.

Because bank capital is costly, $\gamma<\beta$, the extent to which the constrained planner is able to backload dividends to relax market-imposed no-default conditions during a financial crisis is limited. As a result, the dividend payout ratio increases temporarily following financial crises. Banks resume paying dividends earlier in the second-best allocation, compared with the competitive equilibrium, such that, in particular, rebuilding equity buffers takes a backseat to resuming dividend payouts in the aftermath of financial crises.

The constrained planner allows banks to have higher leverage during financial crises. On the one hand, the planner can satisfy market-imposed no-default conditions more easily by increasing bank future profits at relatively small cost. On the other hand, the planner is less averse to risk during crises, compared with banks in the competitive equilibrium, since any potential future equity scarcity can be partially 


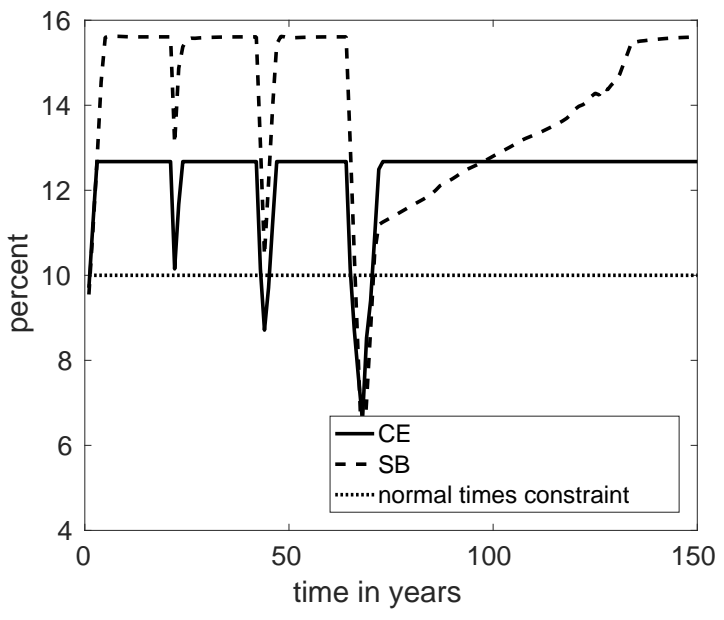

(a) Aggregate bank capital

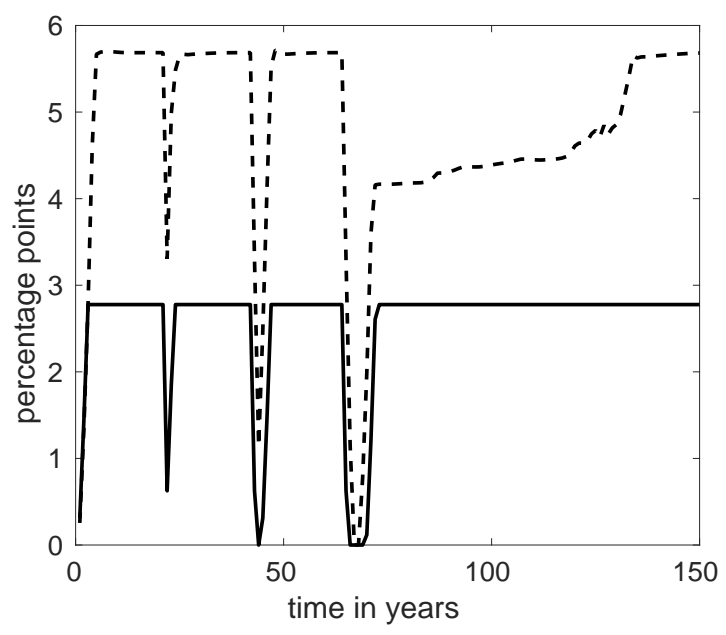

(c) Slack in no-default condition

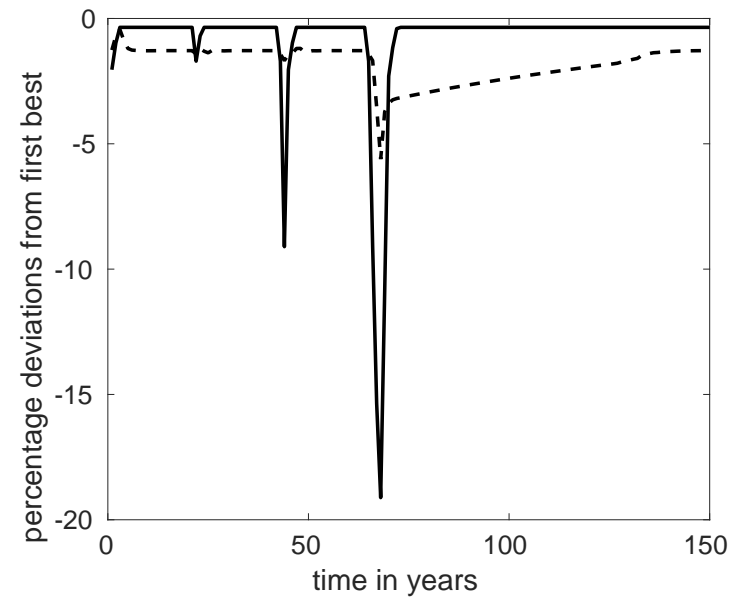

(b) Aggregate bank lending

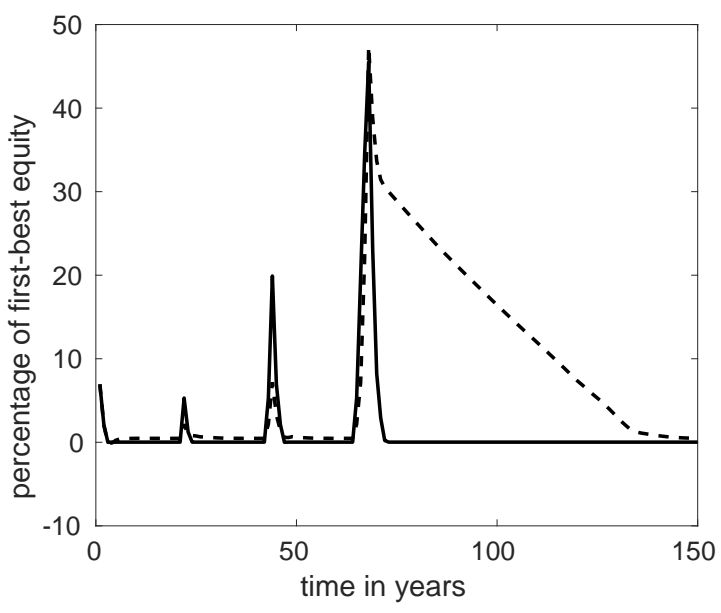

(d) Future profits

Figure 2: Panel (a) shows bank capital relative to bank lending, $\left[\gamma E_{t} A_{t+1} / K_{t+1}-1\right] \cdot 100$, where $E_{t}$ denotes conditional expectations at time $t$. Panel (b) shows bank lending relative to first-best lending, $\left[K_{t+1} / K_{F B}-1\right] \cdot 100$. Panel (c) shows the slack in the market-imposed no-default condition, $\left[\gamma E_{t} V_{t+1} / \theta K_{t+1}-1\right] \cdot 100$. Finally, panel (d) shows bank future profits relative to first-best equity, $\Pi_{t} / \beta \theta K_{F B} \cdot 100$. 


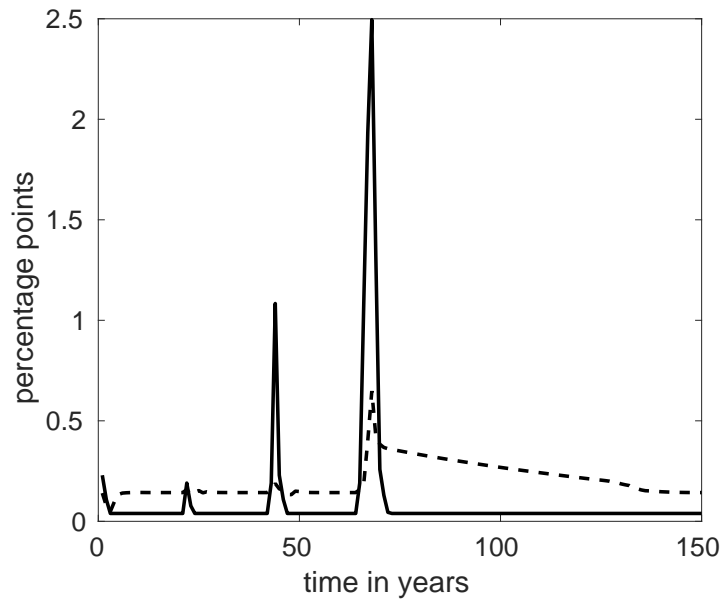

(a) Expected excess lending returns

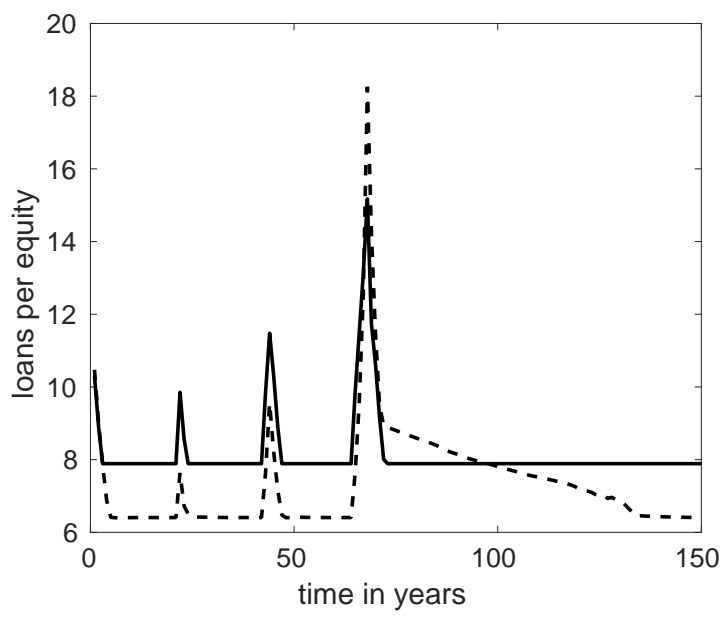

(c) Leverage

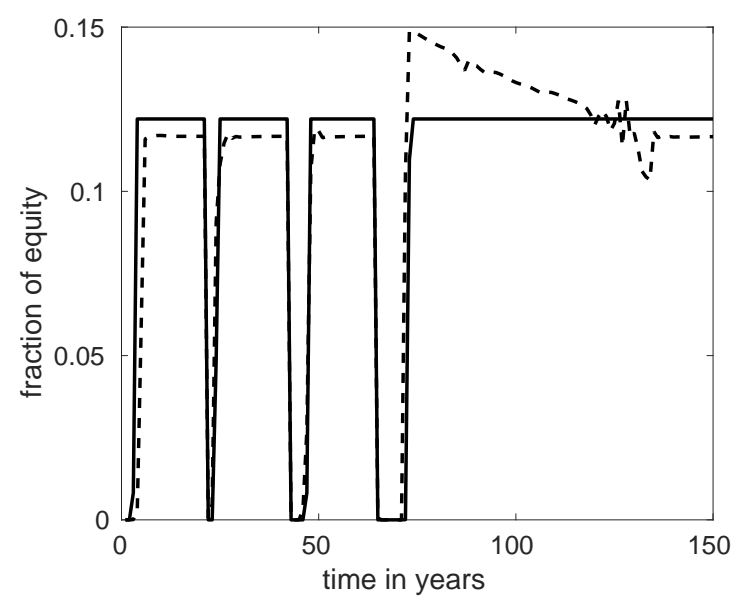

(b) Aggregate dividends

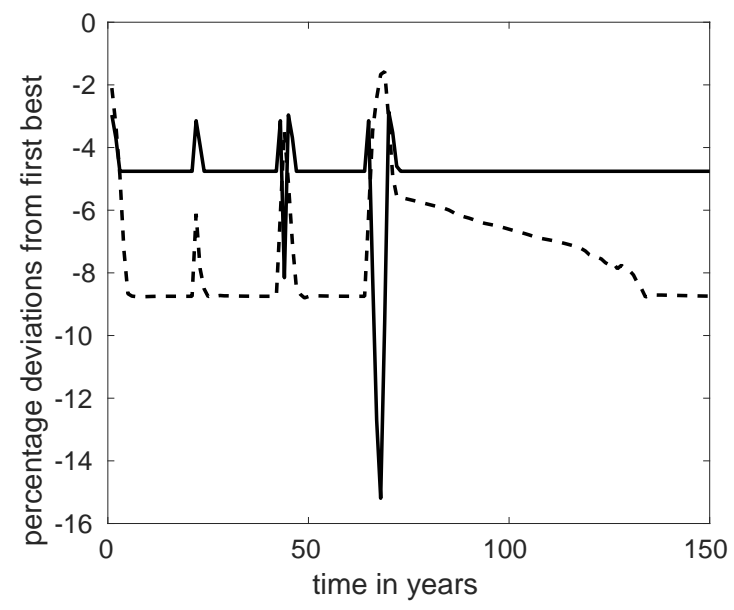

(d) Aggregate bank external funding

Figure 3: Panel (a) shows expected excess returns, $\left[\beta E_{t} R_{t+1}-1\right] \cdot 100$. Panel (b) shows the aggregate bank dividend payout ratio, $D_{t} / A_{t}$. Panel (c) shows bank leverage, $K_{t+1} / \gamma E_{t} A_{t+1}$, which is inversely related to the capital adequacy ratio. Finally, panel (d) shows bank external funding. 
offset by upward adjustments in future profits and since lending returns increase less during crises. Even though the planner prescribes additional equity buffers in normal times, the planner perceives equity to be relatively less scarce during times of financial crisis and is consequently less protective of it. Thus, while the second-best allocation features lower reliance of banks on external funding in normal times, the planner allows banks to aggressively replace lost equity with external funding during times of financial crisis.

Figure 4 shows the economy for a particular random draw of productivity shocks. The competitive equilibrium features a severe credit crunch during years $85-90$. This credit crunch is much less severe in the second-best allocation. However, the economy takes a much longer time to recover from it. The constrained planner uses bank equity more aggressively to maintain lending when bank earnings are low because of low-productivity shocks. The future profits that the planner must promise banks become large, and with them so does the dividend payout ratio. Subsequent low shocks deplete bank equity at periods when it has not yet had time to be rebuilt such that the planner has to adjust promised bank future profits upward repeatedly. As a result, bank margins remain elevated—and bank lending remains depressed—for many years.

The second-best allocation is characterized by macroprudential capital regulation that avoids sharp reductions in bank lending and economic activity but, at the same time, can lead to a very persistent decline in lending and economic activity. One crucial assumption in my analysis is that the constrained planner can honor its promise to deliver bank future profits. 


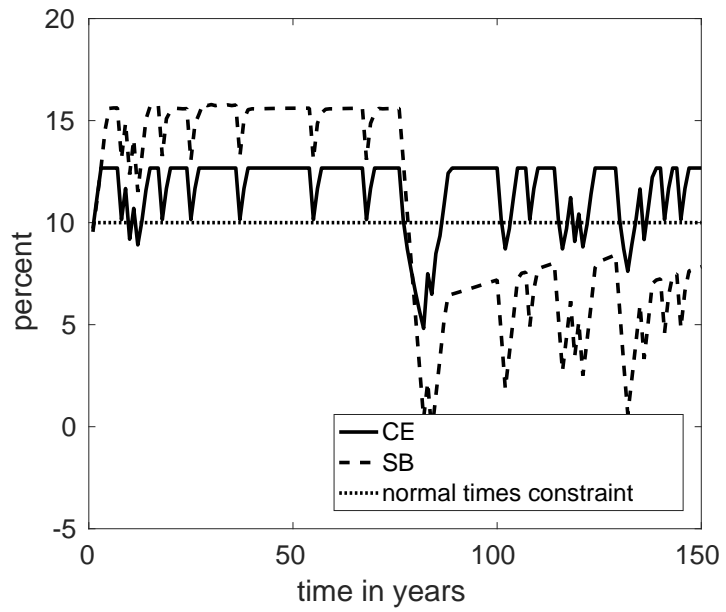

(a) Aggregate bank capital

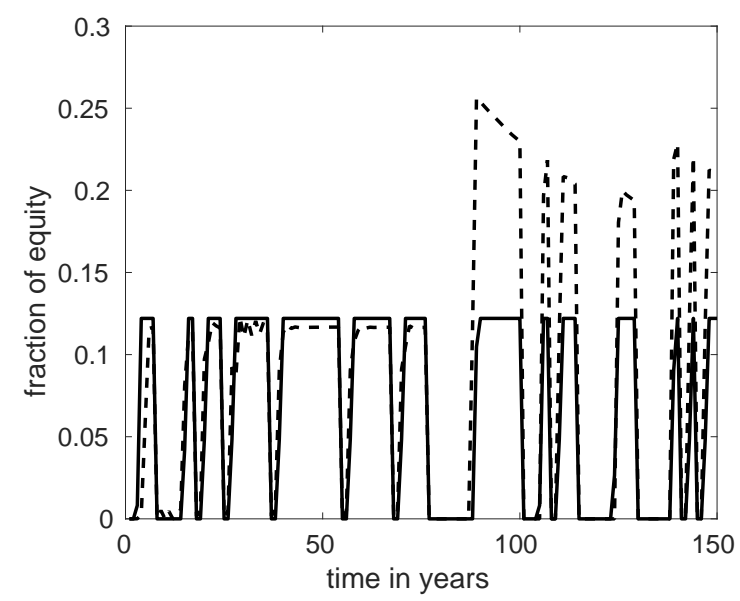

(c) Aggregate dividends

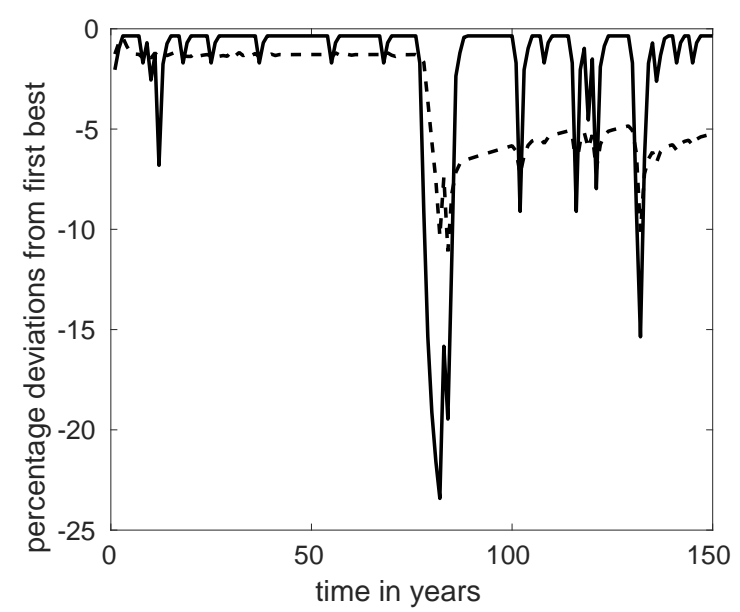

(b) Aggregate bank lending

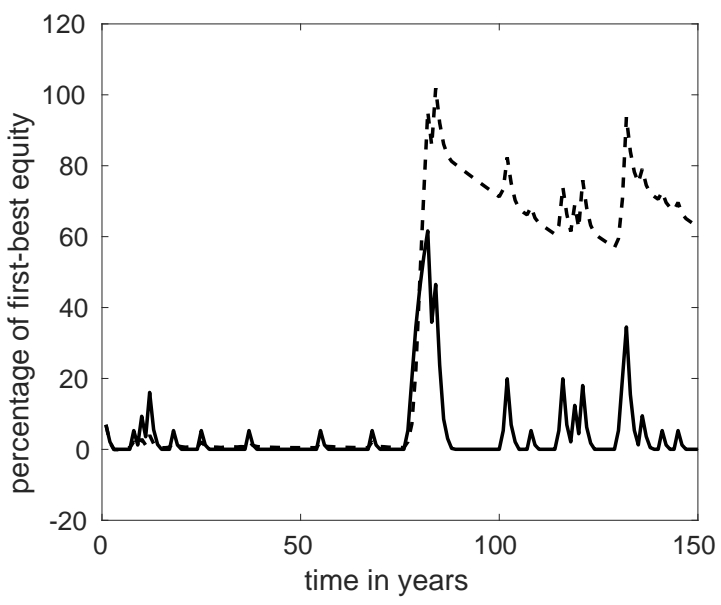

(d) Future profits

Figure 4: Economy for a random sequence of productivity shocks. Panel (a) shows bank capital relative to bank lending, $\left[\gamma E_{t} A_{t+1} / K_{t+1}-1\right] \cdot 100$, where $E_{t}$ denotes conditional expectations at time $t$. Panel (b) shows bank lending relative to first-best lending, $\left[K_{t+1} / K_{F B}-1\right] \cdot 100$. Panel (c) shows aggregate bank dividend payout ratio, $D_{t} / A_{t}$. Finally, panel (d) shows bank future profits relative to first-best equity, $\Pi_{t} / \beta \theta K_{F B} \cdot 100$. 


\subsection{Policy implications}

The second-best allocation shows that there is a net benefit from requiring banks to hold additional equity. Such capital buffers are "always on" in the sense that banks should build them up gradually in good times while paying out dividends at the same time. High non-linearities as well as this gradualism imply that it is too late to turn on the capital buffer once the economy experiences financial stress in the form of losses on bank balance sheets.

Banks should be allowed to use capital buffers during credit crunches-for lending to firms and, eventually, for dividend payments. In case the economy is still in a credit crunch by the time capital buffers are exhausted, bank future rents can be increased to continue to stabilize lending. Bank future rents should be provided by distributing economic distortions over multiple periods, which has the side effect of slowing down the recovery from credit crunches. Credit crunches are much less severe in the secondbest allocation than in competitive equilibrium such that the net effect on welfare is positive. $^{12}$

\subsubsection{Relationship to regulatory practice}

In practice, there is a broad consensus among regulators that banks should hold more capital on average (e.g., Fender and Lewrick, 2016). At the same time regulators have identified a number of "externalities" that determine what they consider the desired level of capital over time. Examples of such externalities are temporarily high levels of debt that might expose borrowers to sudden changes in asset prices, or exchange

\footnotetext{
${ }^{12}$ The second best achieves higher welfare uniformly across every point of the state-space of the competitive equilibrium. Specifically, for given bank equity $a_{0}$ the constrained planner achieves higher welfare compared with the competitive equilibrium when assuming banks are promised the value they can generate in competitive equilibrium for given $a_{0}$.
} 
rates, together with associated feedback effects. ${ }^{13}$ Another externality might be low bank provisioning stemming from a temporary scope to use accounting discretion that might expose the economy to sudden bank deleveraging. ${ }^{14}$ Determining the desired level of bank capital likely requires regulator judgment because not all externalities might be equally important at a given time. Indeed, while the Savings and Loan crisis was clearly related to insufficient recognition of risk by banks, the recent financial crisis was related to excessive borrowing as well as banks' hidden exposures. ${ }^{15}$

In this paper, I focus on a different externality that is related to the price of bank equity. This externality is always important because it arises ex post, conditional on a financial crisis occurring. Specifically, promising banks future profits during a financial crisis lowers concerns about bank moral hazard, and thereby reduces pressure on banks to deleverage. The analysis in this paper suggests that regulation should take seriously its ability to affect bank profitability ex post in a way that complements the existing regulatory focus on addressing risk buildup ex ante.

\subsubsection{Is a capital buffer harsh on banks?}

Requiring banks to accumulate an additional capital buffer imposes costs on the economy since bank equity is costly, $\gamma<\beta$, and since the bank participation constraint (15) states that a bank cannot be forced to continue operating when its value falls short of its equity. An increased level of equity lowers the profits banks earn from leverage and

\footnotetext{
${ }^{13}$ Pecuniary externalities related to the prices of assets or liabilities are well studied (e.g., Lorenzoni, 2008; Bianchi and Mendoza, 2011).

${ }^{14}$ The Bank of Spain developed a provisioning scheme that is backward-looking and thus partially curbs this discretion (Saurina and Trucharte, 2017). Borio (2018) discusses the implications of backwardand forward-looking accounting schemes, respectively, on the effectiveness of prudential regulation.

${ }^{15}$ Regulation often follows a holistic approach in assessing buildup of systemic risk ex ante. One motivation for this is that the set of informative "early warning indicators" that contribute to determining the macroprudential policy stance tends to evolve over time (Aldasoro et al., 2018). In general, challenges in measuring financial distress consistently (Romer and Romer, 2017) might contribute to challenges in designing a consistent framework to forecast financial distress.
} 
makes it necessary for a constrained planner to compensate banks with profits from higher lending returns. In other words, the planner must allow banks to earn a higher return on assets such that banks can achieve their required return on equity with reduced leverage. A planner thus trades off the benefit from increased resilience against the cost of more distorted lending returns when considering the size of a bank's capital buffer. Since bank dividends enter the planner welfare criterion stated in definition 2, the planner chooses a positive capital buffer.

Figures 5 and 6 compare the laissez-faire competitive equilibrium with the secondbest allocation for the case in which bank dividends do not enter the planner welfare criterion at all. For example, a constrained planner may value bank dividends less in the case where foreigners enjoy some of these dividends. Figure 5 shows that a constrained planner that does not value bank dividends at all would ask banks to hold less equity than they do in the competitive equilibrium. In fact, the planner chooses bank lending above the first-best level during normal times. The reason is that the planner prefers that bank cash flows during normal times support wages rather than dividends-even at the cost of imposing losses on banks, lower bank equity and, compared with the case in which the planner values dividends directly, higher volatility of bank lending.

Leverage is higher in the second-best allocation, but severe credit crunches can be avoided by increasing bank future profits whenever banks experience low lending returns (Figures 5(b) and 5(d)). The bank participation constraint is satisfied-despite incurring losses in expectation during normal times-by anticipated temporary increases in profits that are large and frequent. Banks are not profitable during normal times but break even overall, since the planner treats them favorably during times of financial crisis. 
Intuitively, when the planner does not value bank dividends, a high level of bank equity has a social cost that is excessive because of the bank participation constraint (15). As a result of market incompleteness, high realized lending returns lead to bank equity that is too high such that a planner prescribes lending above the first-best level, as well as negative expected lending returns, to achieve the desired lower level of equity. However, the planner still uses bank future profits to stabilize bank lending over time.

A constrained planner that does not value bank dividends would require banks to hold less equity and to lend excessively in good times. Such a planner would not see any reason to impose capital buffers even if credit-to-GDP measures are elevated-in fact, high credit-to-GDP becomes a policy implication. In contrast, a planner that values bank dividends requires banks to hold more equity and somewhat restrict lending in good times. In that sense, a capital buffer is not harsh on banks because it is imposed by the planner that values bank well-being directly. A planner would always-whether valuing dividends or not—stabilize bank lending during credit crunches by adjusting future bank profits upward.

\subsubsection{Tighter-than-necessary microprudential capital requirements}

Figures 7 and 8 compare competitive equilibrium and second-best allocation for the case in which bank future profits do not enter the bank no-default constraint. This case can be interpreted as a microprudential regulator imposing a bank no-default condition that is tighter than the no-default constraint (6) imposed by market participants. The condition is then tighter than necessary to prevent default (Kehoe and Levine, 1993; Alvarez and Jermann, 2000). The additional tightness is ad hoc and not derived from macroprudential concerns. The second-best allocation can then be inter- 


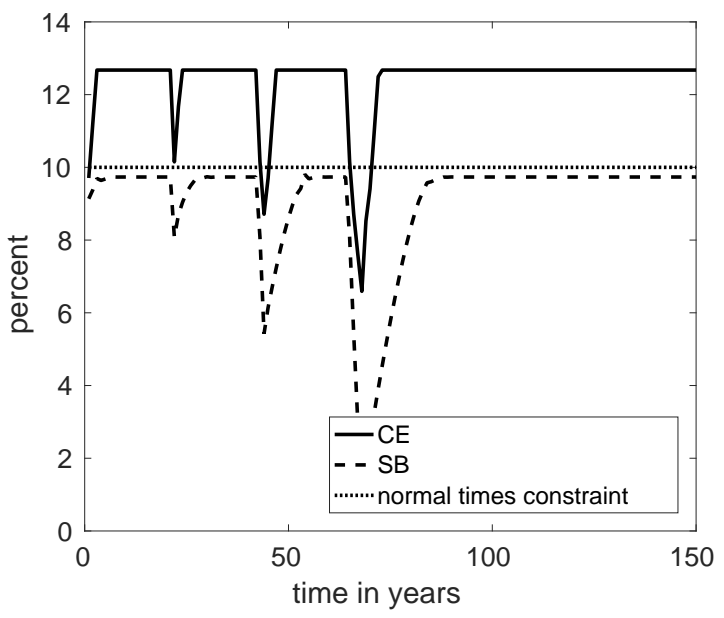

(a) Aggregate bank capital

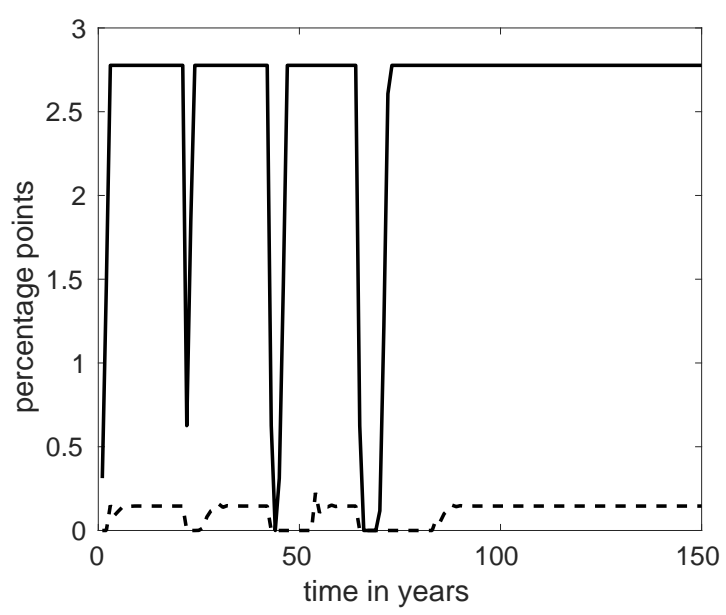

(c) Slack in no-default condition

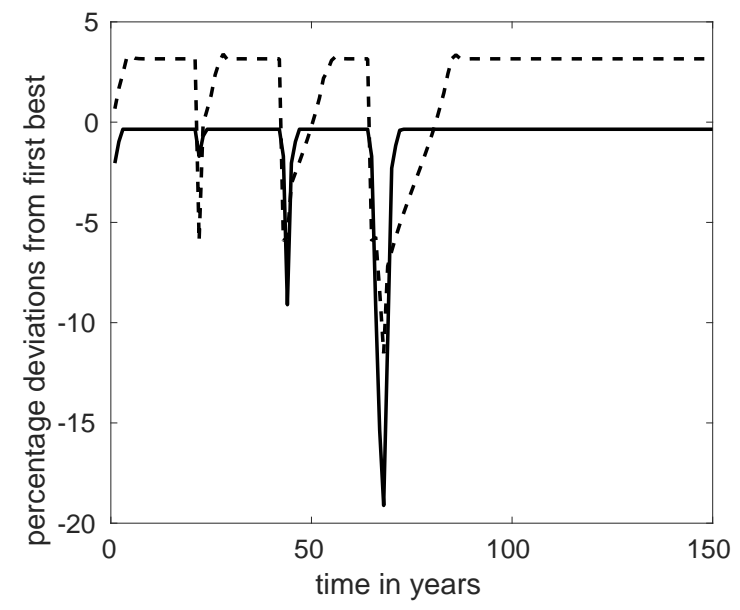

(b) Aggregate bank lending

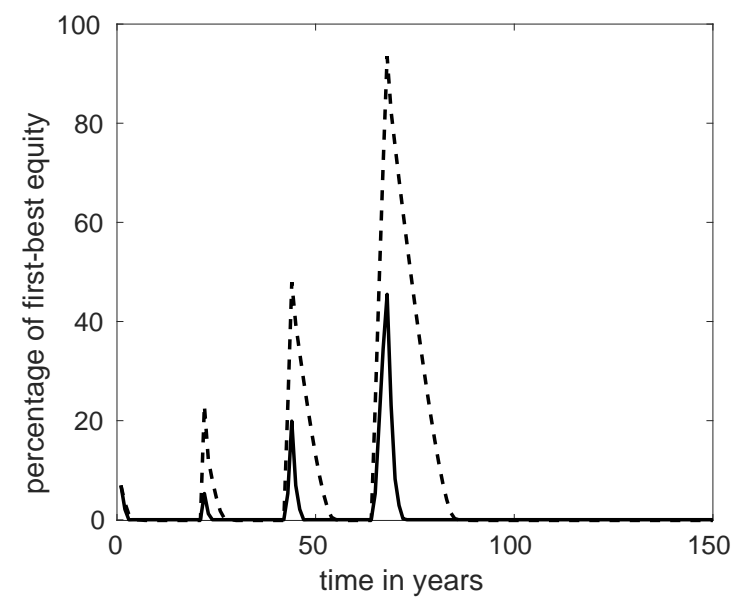

(d) Future profits

Figure 5: Case in which constrained planner does not value bank dividends. Panel (a) shows bank capital relative to bank lending, $\left[\gamma E_{t} A_{t+1} / K_{t+1}-1\right] \cdot 100$, where $E_{t}$ denotes conditional expectations at time $t$. Panel (b) shows bank lending relative to first-best lending, $\left[K_{t+1} / K_{F B}-1\right] \cdot 100$. Panel (c) shows the slack in the market-imposed no-default condition, $\left[{ }_{\gamma} E_{t} V_{t+1} / \theta K_{t+1}-1\right] \cdot 100$. Finally, panel (d) shows bank future profits relative to first-best equity, $\Pi_{t} / \beta \theta K_{F B} \cdot 100$. 


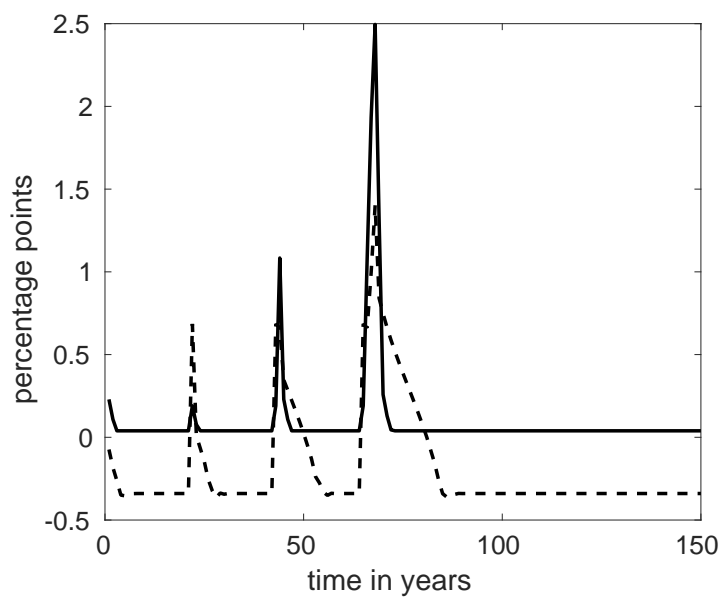

(a) Expected excess lending returns

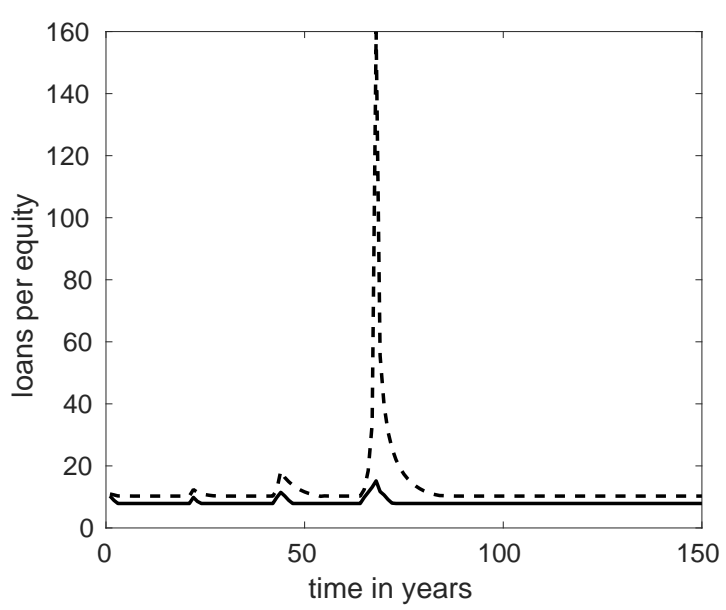

(c) Leverage

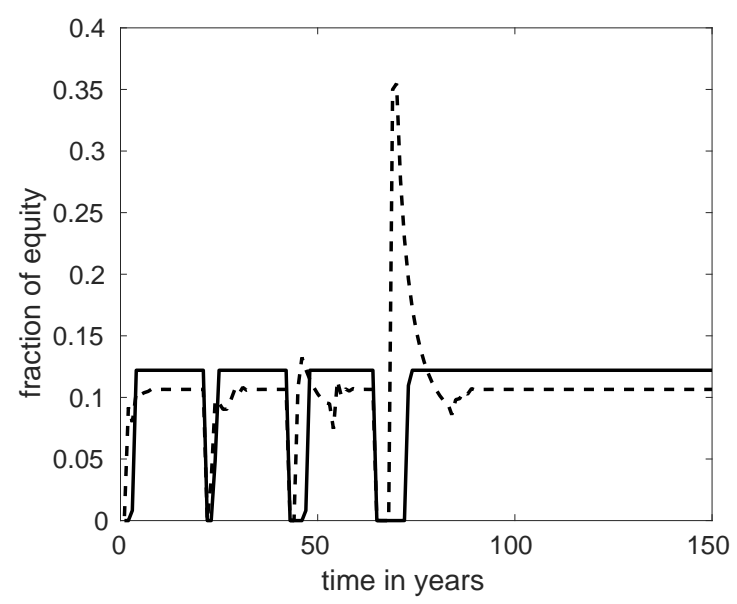

(b) Aggregate dividends

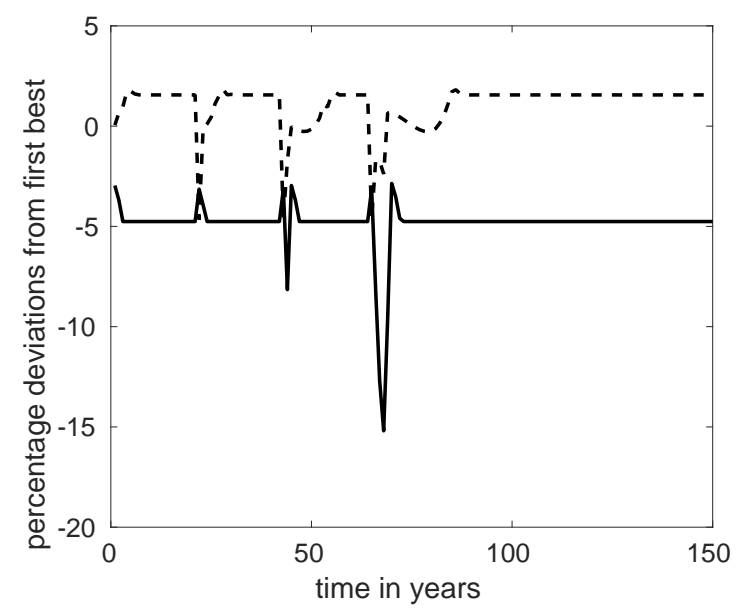

(d) Aggregate bank external funding

Figure 6: Case in which constrained planner does not value bank dividends. Panel (a) shows expected excess returns, $\left[\beta E_{t} R_{t+1}-1\right] \cdot 100$. Panel (b) shows the aggregate bank dividend payout ratio, $D_{t} / A_{t}$. Panel (c) shows bank leverage, $K_{t+1} / \gamma E_{t} A_{t+1}$, which is inversely related to the capital adequacy ratio. Finally, panel (d) shows bank external funding. 
preted as the best allocation a macroprudential regulator can achieve, taking a tight microprudential constraint as given.

Both individual loan loss provisioning and additional capital buffers are now higher. However, the constrained planner does not raise bank future profits to alleviate financial crises. The reason is that for a given tight microprudential bank no-default constraint, there is no scope for the macroprudential regulator to support bank lending in times of financial crisis. The following section studies regulatory capital buffers-capital requirements that are increasing in a bank's current-period bank dividend payout.

\section{Regulatory capital buffers}

The model can be used to study the properties of regulatory capital buffers (see Basel Committee on Banking Supervision, 2010, or "Basel III") in a dynamic economy. Specifically, in Section 5.1 the size of the regulatory capital buffer is a function of endogenous variables, and the focus is on how buffers affect transitional dynamics around financial crises. Section 5.2 uses a simpler capital buffer rule based on exogenous indicators and presents comparative statics with respect to the size of the buffer.

The benchmark model is extended by adding another possible value for productivity shocks as follows:

$$
S=\left\{s_{L}, s_{M}, s_{H}\right\}=\{0.80,1,1.05\}
$$

Further, productivity is now persistent, and the transition matrix $P_{S}=\operatorname{Prob}\left(s_{t+1} \mid s_{t}\right)$ is given as follows:

$$
P_{S}=\left(\begin{array}{ccc}
\rho & 1-\rho & 0 \\
\rho / 2 & 1-\rho & \rho / 2 \\
0 & 1-\rho & \rho
\end{array}\right) \text {. }
$$




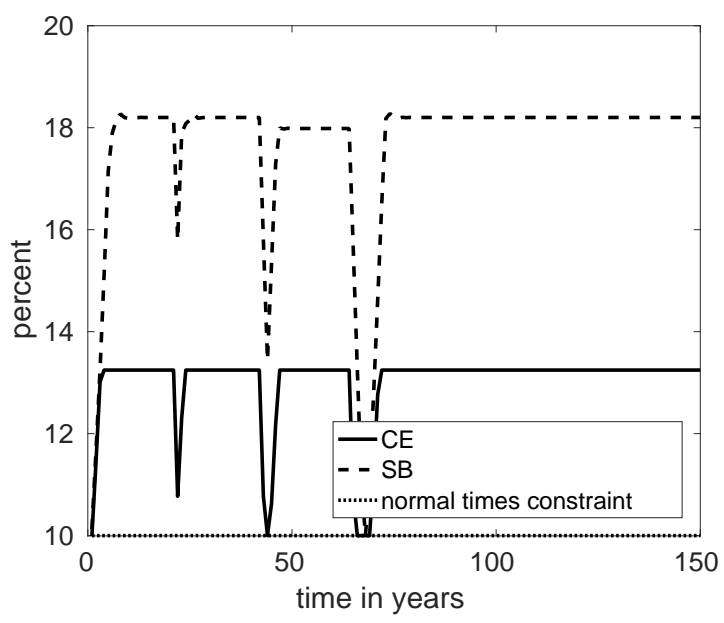

(a) Aggregate bank capital

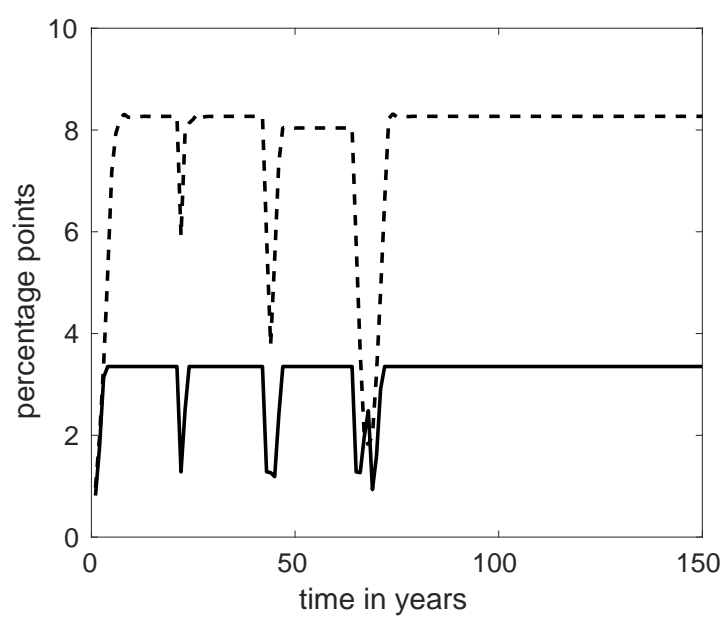

(c) Slack in no-default condition

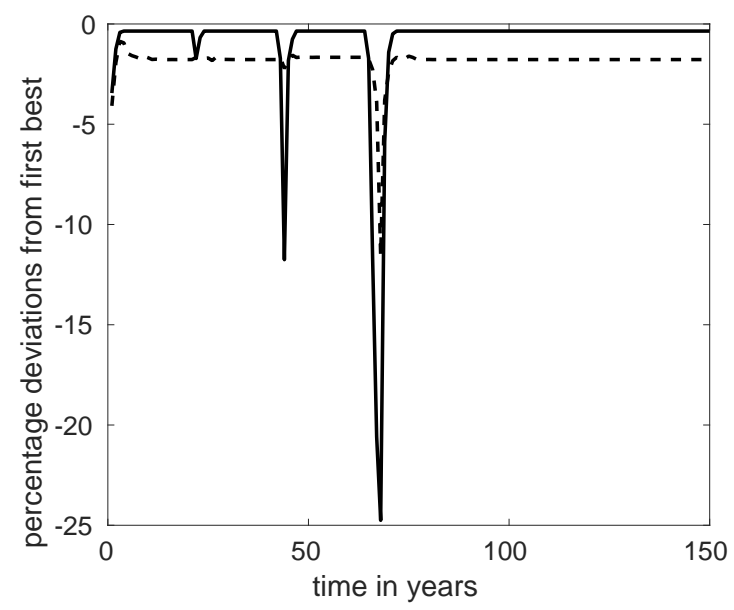

(b) Aggregate bank lending

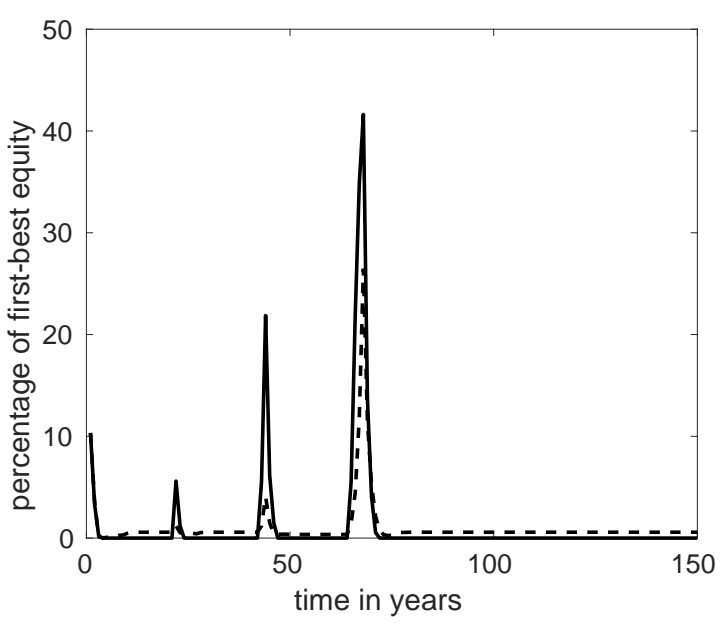

(d) Future profits

Figure 7: Case in which capital requirements do not depend on future profits. Panel (a) shows bank capital relative to bank lending, $\left[\gamma E_{t} A_{t+1} / K_{t+1}-1\right]$. 100 where $E_{t}$ denotes conditional expectations at time $t$. Panel (b) shows bank lending relative to first-best lending, $\left[K_{t+1} / K_{F B}-1\right] \cdot 100$. Panel (c) shows the slack in the market-imposed no-default condition, $\left[{ } E_{t} V_{t+1} / \theta K_{t+1}-1\right] \cdot 100$. Finally, panel (d) shows bank future profits relative to first-best equity, $\Pi_{t} / \beta \theta K_{F B} \cdot 100$. 


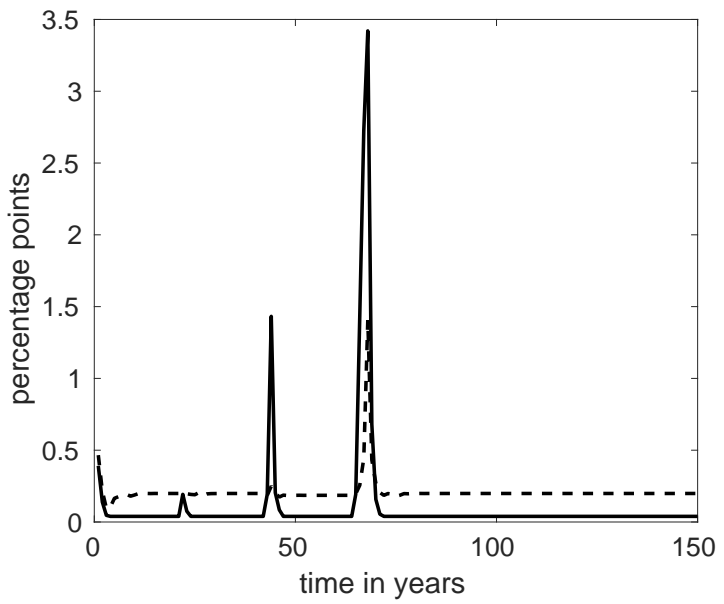

(a) Expected excess lending returns

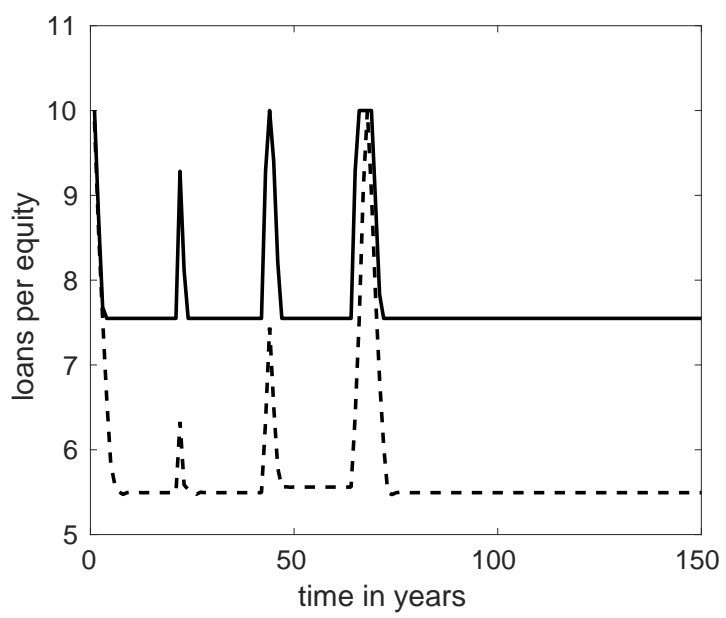

(c) Leverage

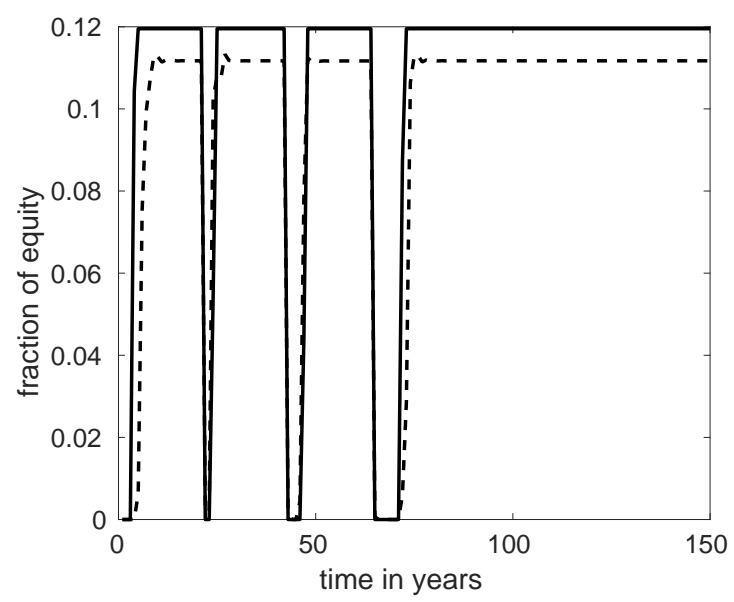

(b) Aggregate dividends

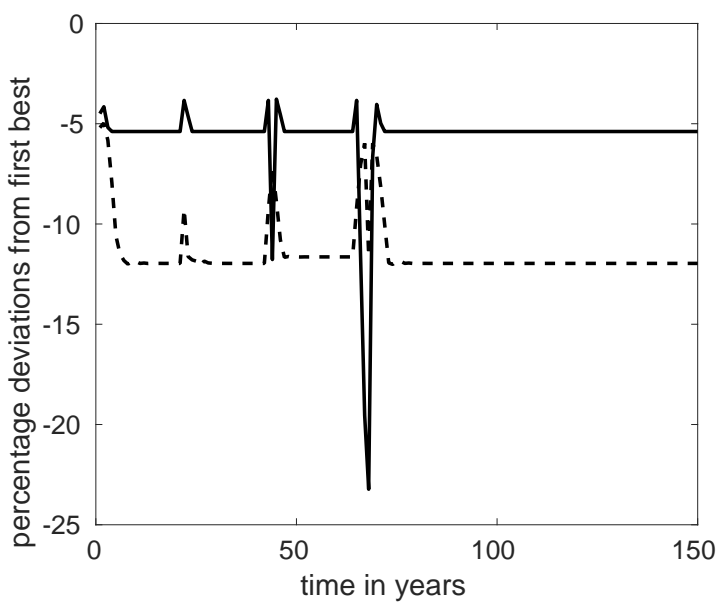

(d) Aggregate bank external funding

Figure 8: Case in which capital requirements do not depend on future profits. Panel (a) shows expected excess returns, $\left[\beta E_{t} R_{t+1}-1\right] \cdot 100$. Panel (b) shows the aggregate bank dividend payout ratio, $D_{t} / A_{t}$. Panel (c) shows bank leverage, $K_{t+1} / \gamma E_{t} A_{t+1}$, which is inversely related to the capital adequacy ratio. Finally, panel (d) shows bank external funding. 
I introduce an exogenous regulatory minimum capital requirement

$$
\gamma \sum_{s_{t+1}} \pi\left(s_{t+1} \mid s_{t}\right) a_{t+1}\left(s^{t+1}\right) \geq \theta_{1} \ell_{t+1}\left(s^{t}\right)
$$

with capital defined as $\gamma \sum_{s_{t+1}} \pi\left(s_{t+1} \mid s_{t}\right) a_{t+1}\left(s^{t+1}\right)$ and set $\theta_{1}=0.06$. I further introduce the following exogenous regulatory dividend payout restriction:

$$
d_{t}\left(s^{t}\right) \leq \tau_{t}\left(s^{t}\right)\left(\gamma \sum_{s_{t+1}} \pi\left(s_{t+1} \mid s_{t}\right) a_{t+1}\left(s^{t+1}\right)-\theta_{1} \ell_{t+1}\left(s^{t}\right)\right) .
$$

The payout restriction (19) limits dividends to a fraction of "eligible earnings" which are simply defined as capital in excess of the minimum requirement. In practice, it is possible to define eligible earnings as a flow variable instead of a stock variable, but the latter may be more robust to bank accounting choices. Note that (19) implies the minimum requirement (18) because of the assumption that dividends must be non-negative.

\subsection{Case of endogenous indicators}

Under Basel III the size of the CCyB is a function of macroeconomic variables. In this section, I set $\tau_{t}\left(s^{t}\right)$ as a function of the ratio of bank lending to expected GDP in a way that equates the size of the capital buffer to the capital buffer in the second-best allocation when bank lending to expected GDP is high. Alternatively, I could have taken two indicators: bank lending to GDP and growth of bank lending. Note that neither of these two indicators is sufficient by itself, but bank lending to expected GDP is. ${ }^{16}$ Figure 9 shows that the effect of the capital buffer is small but significant-bank

\footnotetext{
${ }^{16}$ Bank lending to GDP can be high during a financial crisis when GDP is low, while growth of bank lending can be high during a recovery from a financial crisis. Thus $\tau_{t}\left(s^{t}\right)$ should be either a decreasing
} 

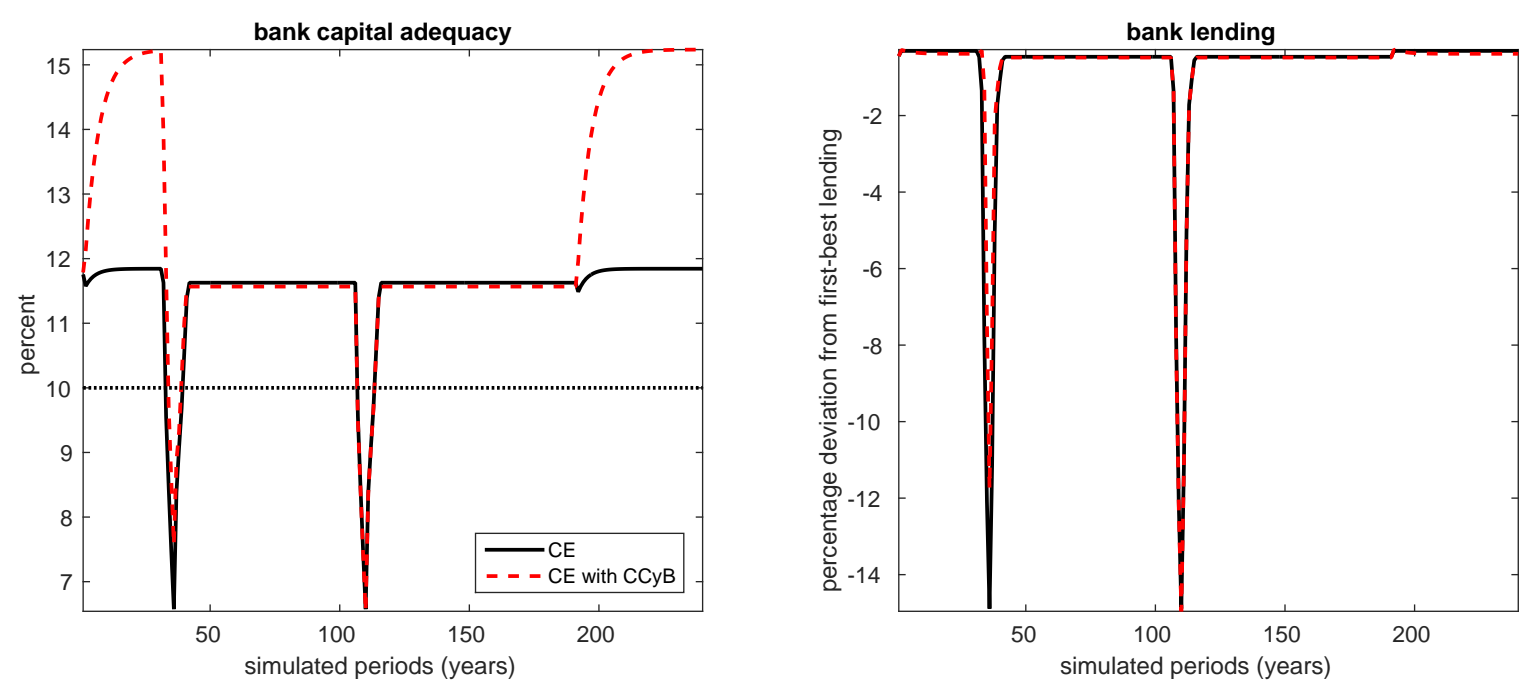

Figure 9: Effect of capital buffer on bank capital and lending over time (in economy with regulatory minimum requirement).

lending drops by two percentage points less when the buffer had been fully built up before the financial crisis.

Figure 10 compares the competitive equilibrium with the regulatory buffer and minimum requirement to a second best in which the regulatory minimum requirement is imposed as well. The main difference is that in second best, buffers are about the same in normal times and boom times. There is no gain from varying the size of the buffer over time- - unless a financial crisis occurs. During the recovery from a financial crisis, buffers should be rebuilt gradually.

\subsection{Comparative statics with exogenous indicators}

Suppose the buffer rule is simple in the sense that $\tau_{t}\left(s^{t}\right)=\tau\left(s_{t}\right)$ depends on $s_{t}$ only. Because banks never pay out dividends in the lowest state $s_{L}$, the payout restriction can be set arbitrarily when $s_{t}=s_{L}$; fix it as $\tau\left(s_{L}\right)=0$. Figures 11 and 12 show welfare and the cost of bank credit, respectively, as a function of $\left(\tau\left(s_{M}\right), \tau\left(s_{H}\right)\right)$. A function of bank lending to expected GDP or a decreasing function of bank lending to GDP as long as growth of bank lending is not too high. 

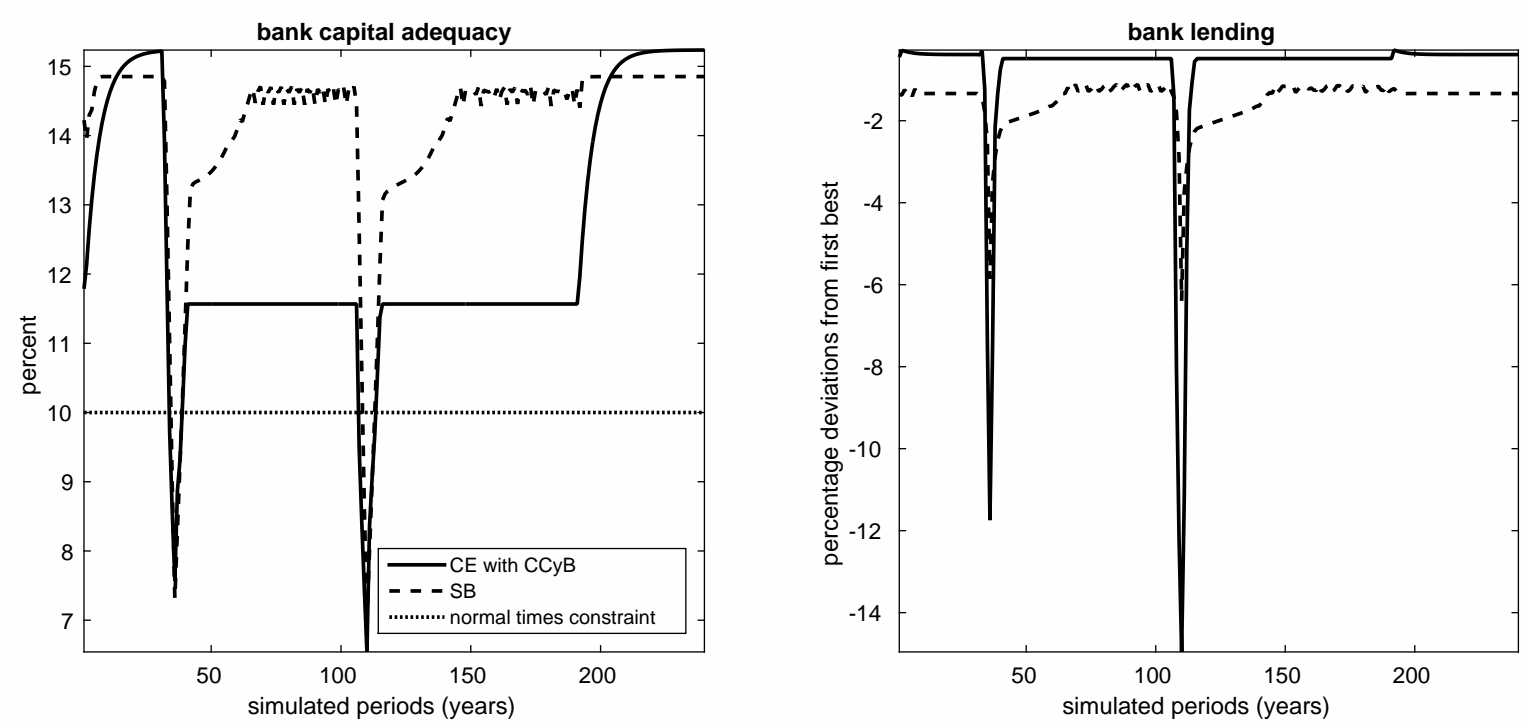

Figure 10: Comparing regulatory and optimal buffers (in economy with regulatory minimum requirement).

lower $\tau$ makes the payout restriction (19) tighter. The lowest possible values for $\tau\left(s_{M}\right)$ and $\tau\left(s_{H}\right)$ - "tightness" of 1 in Figures 11 and 12-are the ones that make the bank participation constraint (15) bind.

Regulation asks banks to retain some of their windfall profits during times of economic boom. The idea is to use them to absorb losses in case the boom is followed by a bust. The role of buffers in normal times is to preserve some of the buffer built up during the boom and avoid that it is immediately paid out as soon as the boom ends. The same intuition also applies to the second-best buffers shown in Figure 10.

\subsection{Buffer cyclicality}

Figure 10 shows that the buffer a constrained planner would prefer is not necessarily higher in normal times than in boom times. In that sense there is nothing special about boom times when thinking about optimal buffer size. Indeed, Figure 13 shows that in the case in which there is no exogenous regulatory minimum requirement on 


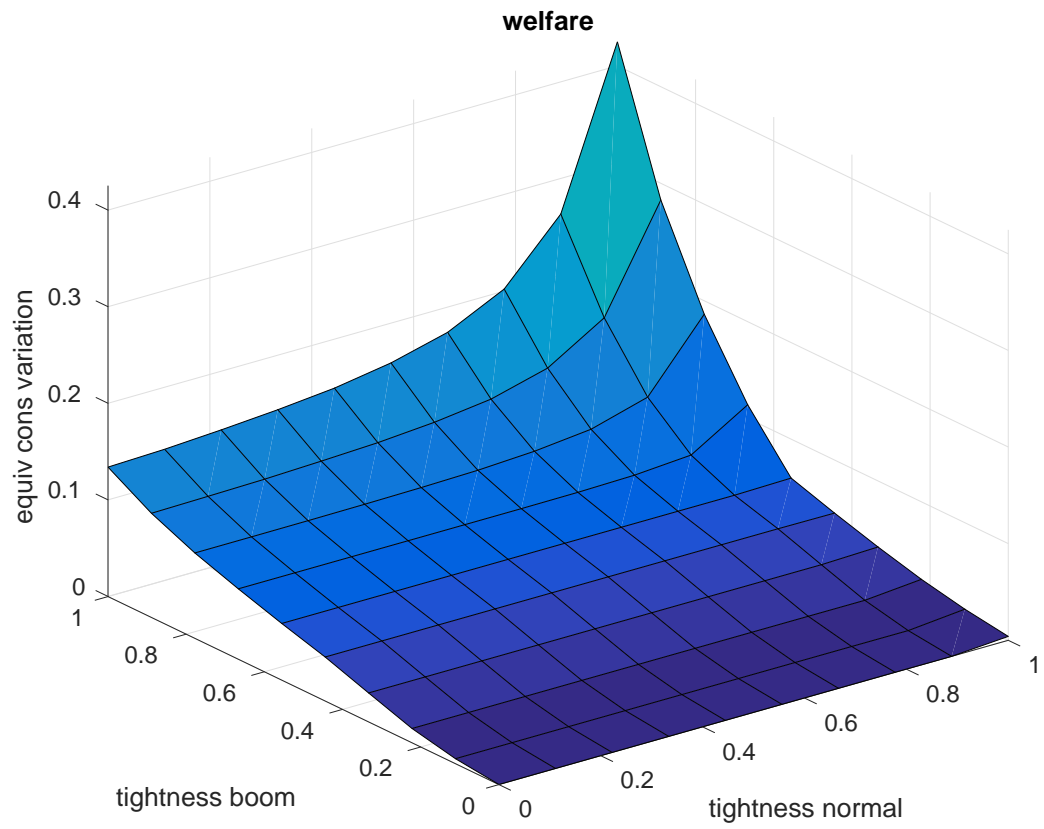

Figure 11: Effect of simple capital buffer on welfare.

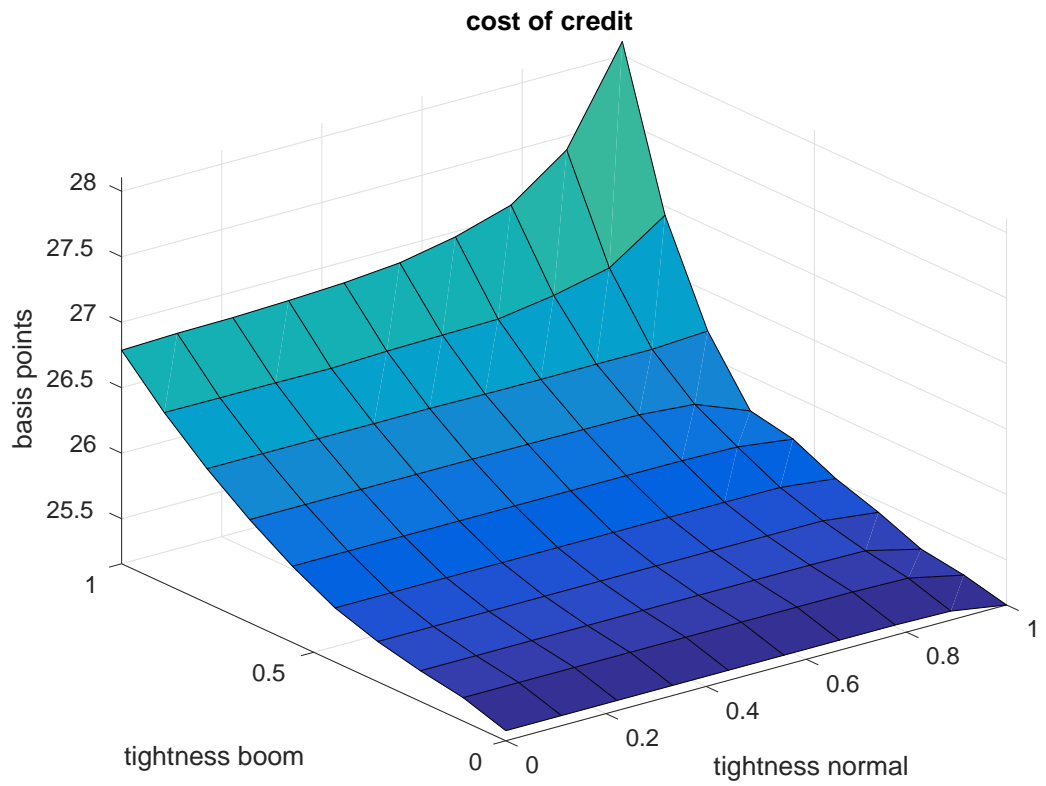

Figure 12: Effect of simple capital buffer on cost of credit. 

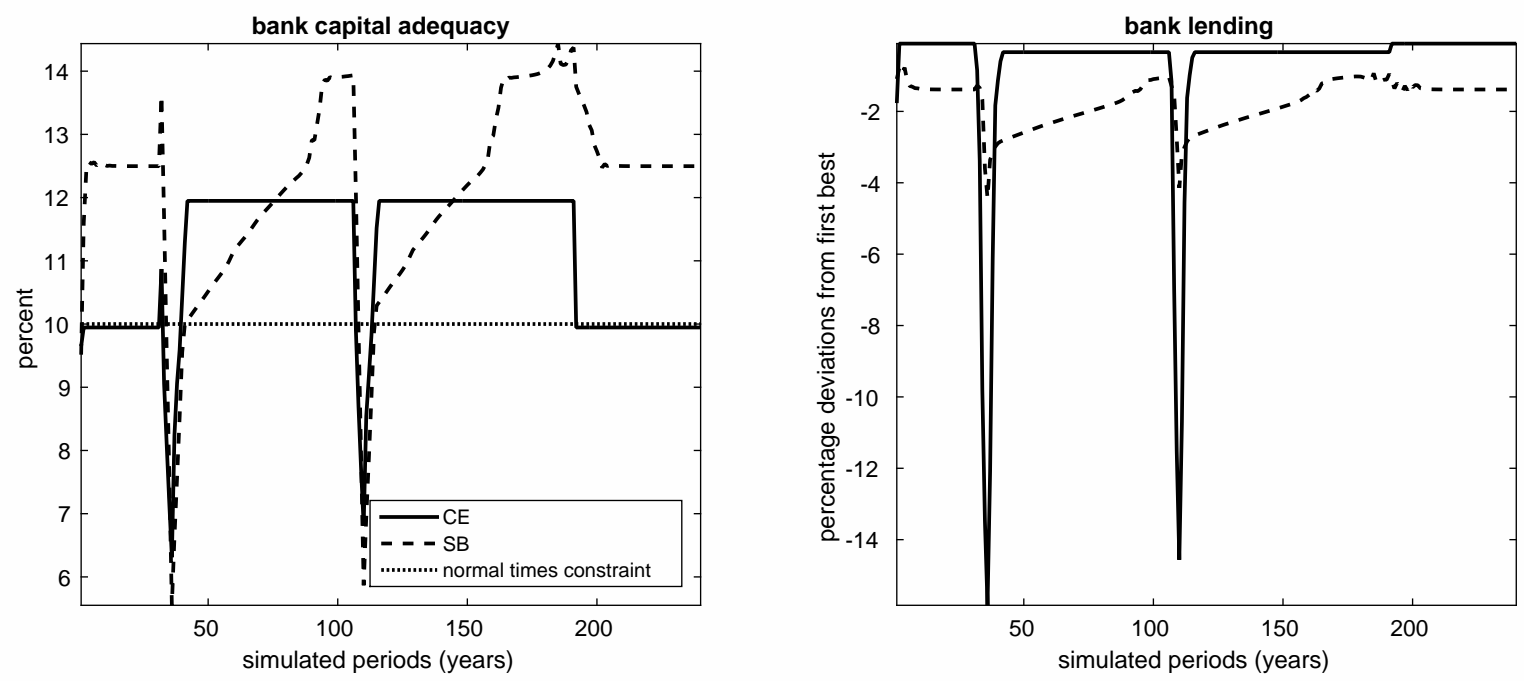

Figure 13: Comparing competitive equilibrium and second best (in economy without regulatory minimum requirement).

top of the market-imposed equity requirement, the optimal buffer is actually higher in normal times compared with boom times. The reason is that bank losses are still far away, in expectation, during a boom. Paradoxically, therefore, the rationale of higher buffers in boom times might be to provision for binding regulatory constraints rather than actual bank losses.

\section{Conclusion}

Banks may lose access to external funding on occasion. This can create a socially costly credit crunch in the economy during which banks are forced to reduce their lending activity. This paper studies constrained-efficient capital regulation that aims to prevent and mitigate such credit crunches and derives two implications for macroprudential policy. First, additional capital buffers should be imposed ex ante. Because of strong non-linearities present in the model, such buffers should be always activated. Second, capital requirements and buffers should be reduced ex post during severe credit 
crunches. Bank default at increased levels of leverage is avoided by granting higher future profits to banks. A macroprudential regulator would affect bank profitability dynamically to smooth out the scarcity of bank lending over financial cycles.

The main policy implication is that capital buffers should be large eventually-however, banks should be given sufficient time to rebuild them during recoveries from financial crises. The idea is to prevent treating banks harshly in the immediate aftermath of a crisis to avoid adding to concerns about bank moral hazard during crises. The pressure on banks to return external funding during a crisis is then lessened such that they can use buffers to maintain lending as much as possible. The CСyB under Basel III is time-varying and therefore can potentially be designed to take into account these implications.

\section{References}

Adrian, T., E. Etula, and T. Muir (2014). Financial intermediaries and the cross-section of asset returns. The Journal of Finance 69(6), 2557-2596.

Aldasoro, I., C. Borio, and M. Drehmann (2018). Early warning indicators of banking crises: Expanding the family. BIS Quarterly Review.

Alvarez, F. and U. J. Jermann (2000). Efficiency, equilibrium, and asset pricing with risk of default. Econometrica 68(4), 775-798.

Basel Committee on Banking Supervision (2010). Basel III: A global regulatory framework for more resilient banks and banking systems.

Bebchuk, L. A. and I. Goldstein (2011). Self-fulfilling credit market freezes. Review of Financial Studies 24(11), 3519-3555. 
Begenau, J. (2014). Capital requirement, risk choice, and liquidity provision in a business cycle model.

Bernanke, B. (2018). The real effects of the financial crisis. In Brooking Papers on Economic Activity, Conference Drafts, September, Volume 13.

Bianchi, J. and E. G. Mendoza (2011). Overborrowing, financial crises and "macroprudential" policy. NBER Working Paper.

Borio, C. (2018). New loan provisioning standards and procyclicality. Panel remarks prepared for conference on "The new bank provisioning standards: Implementation challenges and financial stability implications".

Clerc, L., A. Derviz, C. Mendicino, S. Moyen, K. Nikolov, L. Stracca, J. Suarez, A. P. Vardoulakis, et al. (2015). Capital regulation in a macroeconomic model with three layers of default. International Journal of Central Banking 11(3), 9-63.

Fender, I. and U. Lewrick (2016). Adding it all up: The macroeconomic impact of Basel II and outstanding reform issues. BIS Working Paper (No 591).

Gorton, G. and A. Metrick (2012). Securitized banking and the run on repo. Journal of Financial Economics 104(3), 425-451.

Greenwald, B. C. and J. E. Stiglitz (1986). Externalities in economies with imperfect information and incomplete markets. The Quarterly Journal of Economics 101(2), 229264.

He, Z. and A. Krishnamurthy (2013). Intermediary asset pricing. American Economic Review 103(2), 732-770. 
Hellmann, T. F., K. C. Murdock, and J. E. Stiglitz (2000). Liberalization, moral hazard in banking, and prudential regulation: Are capital requirements enough? American Economic Review, 147-165.

Huizinga, H. and L. Laeven (2012). Bank valuation and accounting discretion during a financial crisis. Journal of Financial Economics 106(3), 614-634.

Jeanne, O. and A. Korinek (2013). Macroprudential regulation versus mopping up after the crash. Technical report, National Bureau of Economic Research.

Kehoe, T. J. and D. K. Levine (1993). Debt-constrained asset markets. Review of Economic Studies 60(4), 865-888.

Laeven, L. and F. Valencia (2013). Systemic banking crises database. IMF Economic Review 61(2), 225-270.

Lorenzoni, G. (2008). Inefficient credit booms. Review of Economic Studies 75(3), 809-833.

Martinez-Miera, D. and J. Suarez (2012). A macroeconomic model of endogenous systemic risk taking. Centre for Economic Policy Research.

Moyen, S. and J. Schroth (2018). A calibrated model of optimal bank capital regulation. Unpublished manuscript, Bank of Canada.

Muir, T. (2017). Financial crises and risk premia. The Quarterly Journal of Economics 132(2), 765-809.

Perotti, E. C. and J. Suarez (2002). Last bank standing: What do I gain if you fail? European Economic Review 46(9), 1599-1622.

Philippon, T. and P. Schnabl (2013). Efficient recapitalization. The Journal of Finance 68(1), 1-42. 
Rampini, A. and S. Viswanathan (2010). Collateral, risk management, and the distribution of debt capacity. The Journal of Finance 65(6), 2293-2322.

Rampini, A. A. and S. Viswanathan (2018, 04). Financial Intermediary Capital. The Review of Economic Studies 86(1), 413-455.

Repullo, R. (2013). Cyclical adjustment of capital requirements: A simple framework. Journal of Financial Intermediation 22(4), 608-626.

Repullo, R. and J. Suarez (2013). The procyclical effects of bank capital regulation. Review of Financial Studies 26(2), 452-490.

Romer, C. D. and D. H. Romer (2017). New evidence on the aftermath of financial crises in advanced countries. American Economic Review 107(10), 3072-3118.

Sandri, D. and F. Valencia (2013). Financial crises and recapitalizations. Journal of Money, Credit and Banking 45(s2), 59-86.

Saurina, J. and C. Trucharte (2017). The countercyclical provisions of the Banco de España 2000-2016. Technical report, Banco de España.

Schroth, J. (2016). Optimal intermediary rents. American Economic Journal: Macroeconomics 8(1), 98-118. 